\title{
ResearchOnline@JCU
}

This is the author-created version of the following work:

Veth, Peter, McDonald, Jo, Ward, Ingrid, O'leary, Michael, Beckett, Emma, Benjamin, Jonathan, Ulm, Sean, Hacker, Jörg, Ross, Peter J., and Bailey, Geoff (2020) A strategy for assessing continuity in terrestrial and maritime landscapes from Murujuga (Dampier Archipelago), North West Shelf, Australia. Journal of Island and Coastal Archaeology, 15 (4) pp. 477-503.

Access to this file is available from: https://researchonline.jcu.edu.au/58167/

Copyright (c) 2019 Taylor \& Francis Group, LLC. In accordance with the publisher's policies, this Author Accepted Manuscript for this article is available Open Access from ResearchOnline@JCU.

Please refer to the original source for the final version of this work: 


\section{A Strategy for Assessing Continuity in Terrestrial and Maritime Landscapes from Murujuga (Dampier Archipelago), North West Shelf, Australia}

Peter Veth $^{\mathrm{a}^{*}}$, Jo McDonald ${ }^{\mathrm{a}}$, Ingrid Ward ${ }^{\mathrm{b}, \mathrm{c}}$, Michael O’Leary ${ }^{\mathrm{d}}$, Emma Beckett ${ }^{\mathrm{a}}$, Jonathan Benjamin ${ }^{\mathrm{b}}$, Sean Ulm $^{\mathrm{e}}$, Jorg Hacker ${ }^{\mathrm{f}, \mathrm{g}}$, Peter J. Ross ${ }^{\mathrm{b}}$ and Geoff Bailey ${ }^{\mathrm{b}, \mathrm{h}}$

a Centre for Rock Art Research and Management, School of Social Sciences, Archaeology, The University of Western Australia, M257, UWA, 35 Stirling Highway, Crawley, WA 6009, Australia peter.veth@uwa.edu.au; jo.mcdonald@uwa.edu.au; emma.beckett@research.uwa.edu.au

b College of Humanities, Arts and Social Sciences, Flinders University, GPO Box 2100, Adelaide, SA 5001, Australia ingrid.ward@flinders.edu.au; jonathan.benjamin@flinders.edu.au; peter.ross@flinders.edu.au c School of Social Sciences, Faculty of Arts, Business, Law and Education, Archaeology, The University of Western Australia, M257, UWA, 35 Stirling Highway, Crawley WA 6009, Australia d School of Molecular and Life Sciences, Curtin University of Technology, Kent Street, Bentley, WA 6102, Australia mick.oleary@uwa.edu.au

e ARC Centre of Excellence for Australian Biodiversity and Heritage, College of Arts, Society and Education, James Cook University, PO Box 6811, Cairns, QLD 4870, Australia sean.ulm@jcu.edu.au f ARA-Airborne Research Australia, PO Box 335, Salisbury South, SA 5106, Australia jorg.hacker@flinders.edu.au

g College of Science and Engineering, Flinders University, GPO Box 2100, Adelaide SA 5001, Australia h Department of Archaeology, University of York, The King's Manor, York YO1 7EP, United Kingdom geoff.bailey@york.ac.uk

* Corresponding author 


\begin{abstract}
Over the last 20,000 years, one-third of the continental land mass of Australia, or 2.12 million $\mathrm{km}^{2}$, has been drowned by postglacial sea-level rise. Much of this drowned territory is thought to have been occupied by humans. Where archaeological remains have survived inundation, they can be investigated by underwater and airborne remote sensing, survey, and ground-truthing. This study of the Dampier Archipelago of NW Australia is contextualised by a review of the current state of the art of underwater prehistory. In the absence of known sites, we propose terrestrial analogy as a predictive tool for targeting submerged archaeological sites. Geological and topographic contexts are important for assessing preservation potential as is identifying landforms and features around which people may have focused occupation. Analysis of more than 2,500 known archaeological sites from the extraordinarily rich Dampier Archipelago reveals that the vast majority are rock art sites, but these are interspersed by a significant number of artifact scatters, myriad stone structures, shell middens, and quarry and reduction areas. The majority of these sites are focused on coastal and interior valleys, associated uplands and coastal embayments. While over two-thirds of sites occur on granophyre and basalt substrates, the others are located on quaternary sediments. Regional research on nearby continental islands shows that use of these environments can be expected to pre-date sea level rise. The most likely submerged sites include: 1) compacted middens associated with rock pools and estuarine features; 2) stone structures with associated middens on limestone pavements or with granophyre and basalt boulder fields; 3 ) buried midden and other occupation deposits on protected sand sheets; 4) quarry outcrops, extraction pits, and associated reduction debris in areas of fine-grained granophyre and basalt; and 5) middens in consolidated calcarenite shoreline contexts to the north and west of the volcanic suites of the Dampier Archipelago.
\end{abstract}

\title{
Keywords
}

marine archaeology; submerged sites; prospection; submerged landscapes 


\section{Introduction}

Since 65,000-50,000 years ago - the currently accepted earliest date-range for human entry into Australia and New Guinea (Clarkson et al. 2017; David et al. 2011; Hamm et al. 2016; Maloney et al. 2018; McDonald et al. 2018a; Veth et al. 2017a) - one third of the continental land mass of Sahul has been drowned by postglacial sea-level rise. As in other parts of the world, there is good reason to expect that prior to inundation, this drowned territory offered attractive landscapes and resources for human occupation, and that features of this drowned landscape and their associated archaeological remains have survived inundation and can be retrieved by underwater exploration (Bailey et al. 2017; Benjamin et al. 2011a; Evans et al. 2014; Ulm 2011; Ward et al. 2013, 2015). In Australia, particularly in its north, there is added incentive to explore these drowned landscapes and their coastlines because they would have been the primary point of entry for initial colonization and population dispersal (Bird et al. 2018). Despite lingering uncertainties in the discipline at large about the feasibility, information value and/or cost-effectiveness of underwater archaeological research, the existence of well-preserved Pleistocene or early Holocene records, including evidence of early maritime activities, is well-recognized. The question now being addressed by a growing worldwide community of scientists and scholars interested in this theme is not whether underwater research is worth doing, or why it might be important, but how to go about doing it in the most effective way. The greatest challenge is how to conduct systematic underwater survey with the best chances of success.

Our aim in this paper is to summarize the current state of the art in searching for archaeological traces of human activity on submerged landscapes, and to discuss how we, through the Deep History of Sea Country (DHSC) project, are setting about developing a systematic procedure for underwater investigation of the submerged landscapes within and surrounding the Dampier Archipelago (Murujuga) of NW Australia. The geographical focus of the DHSC project on the Dampier Archipelago is predicated not only on its rich and ancient archaeological record, but also, importantly, because of its diverse geological and geomorphological contexts that offer a range of archaeological sites and associated landscape features to be explored.

In our search for submerged archaeological sites we take a hierarchical approach. We first analyze the currently known types of archaeological sites on land and their geological, geomorphological, and environmental associations. We then undertake a regional-scale assessment of the currently known geological and topographic features of the now-submerged offshore landscape in order to predict suitable contexts for site occurrence and preservation. While it is tempting to assume some degree of continuity between the now-submerged archaeological landscape and the present-day terrestrial one — or at any rate, analogous features below and above present sea-level (Deeben et al. 2002; Chapman and Lillie 2004; Hosfield 2007) - this needs to ideally rely on geological and geomorphological principles (Bates et al. 2007) and, where possible, on precise chronology (see also Ward 2014). However, in the absence of marine stratigraphic, paleoenvironmental, or geochronological data, comparisons are initially divided into hard (crystalline) rock and soft (sedimentary) rock contexts, with the relative age of a potential site or deposit based on bathymetry (i.e., depth below modern sea level) and morphological setting. These essentially inform and delineate prospective target areas for broad-scale underwater mapping. Where paleolandforms known to host cultural site types are identified (based on the terrestrial record), these are then targeted for detailed mapping and diver observations. Direct sampling is then aimed at ground-truthing as a means to correlate onshore and offshore depositional contexts and also to provide a better understanding of changing coastal contexts/site formation processes around these drowned sites or features. 


\section{Current State of the Art in Underwater Prehistory}

During the past decade, there has been an acceleration of interest in and expansion of knowledge of submerged archaeological sites in areas once thought unlikely, such as the Adriatic and Black Seas and along the Atlantic Façade (e.g., Benjamin et al. 2011b; Cassen et al. 2011; Filipova-Marinova et al. 2011). There is increased optimism that archaeological material can survive inundation, a realization of just how much of the evidence for past human use of coastlines must lie hidden on the continental shelf, and a growing recognition of the importance of sea-level change and its past and future impact on the preservation of sites. At the same time, the development of new high-resolution technologies for underwater remote sensing and investigation allow for more systematic approaches for prospection of drowned archaeological sites (Missiaen et al. 2017, Tizzard et al. 2014).

To date, the majority of underwater sites have been discovered by chance rather than by systematic survey, by reports from sports divers, the fortuitous recovery of artifacts by fisher-people and other offshore industries, or due to erosion and exposure of cultural material by storm action in the intertidal zone. More recent examples come from the North Sea, where collaboration between offshore industries, government heritage agencies, and archaeologists has resulted in some remarkable finds, including well-preserved flint handaxes and megafaunal remains from the Late Pleistocene (Bynoe et al. 2016; Moree and Sier 2015; Tizzard et al. 2015). Purposeful survey for underwater sites has been relatively rare, mainly because of the uncertain chances of finding material relative to the high costs and logistical difficulties of mounting underwater expeditions. Examples of successful prediction and targeting of underwater finds are known, for example, from early work on the American continental shelf using sites and site locations on land to predict locations underwater, followed up by acoustic survey and coring or grab sampling (Dixon and Monteleone 2014; Faught 2004; Fedje and Josenhans 2000; Pearson et al. 2014). Fischer's (1993, 1995) fishing site model has also proved successful in finding underwater sites in Denmark, though it is not without its limitations (Grøn 2018).

Development of predictive models based on known archaeological sites on land, reconstruction of submerged topographic features using a combination of diver inspection, video, and acoustic survey, and testing and retrieval of archaeological remains using coring, grab sampling or excavation, are common elements of research strategies on both sides of the Atlantic. Nevertheless, projects that systematically target the search for archaeological sites in this way remain relatively rare, and much archaeologically informed investigation of underwater prehistory has been concentrated in the first instance on reconstruction of submerged landscapes as a first step towards archaeological survey (e.g. Bailey et al. 2015, 2017; Gaffney et al. 2007, 2009, 2017). One of the key principles to emerge from these pioneering studies is that predictive modelling of underwater sites must take account of two issues:

1) the location of topographic features likely to have been attractive to past settlement and the accumulation of discarded cultural material; and

2) the identification of locations where the archaeological material has survived the potentially destructive effects of marine erosion during the early stages of inundation by sea-level rise and is potentially discoverable by visual inspection, remote sensing, coring, or erosion of overlying marine-sediment cover (Bailey et al. in press; Erlandson 2016; Flemming et al. 2017). 
This second issue is a significant challenge and has been discussed by Ward et al. (1999, 2013, 2015) and acknowledged in the development of predictive models for the Murujuga survey discussed below. The main focus of this paper is on the first issue, using analogy with known terrestrial sites.

\section{Regional Geological, Geomorphological and Archaeological Contexts of the Deep History of Sea Country Project}

\subsection{Geological/Geomorphological Setting}

The Dampier Archipelago (Murujuga) represents the westernmost extension of the Archean-age Hamersley Basin. The NW-SE trending Eastern Archipelago, including the Burrup Peninsula, is comprised of 2.7 billion-year-old massive, homogeneous, medium-to-fine grained Gidley Granophyre and a medium-to-coarse grained gabbro. Poorly exposed porphyritic granitoid rock is found along the eastern side of the Burrup Peninsula. The archipelago's western islands are comprised primarily of 2.7 to 2.6 billion-year-old basaltic and andesitic volcanics, with minor outcrops of the Gidley Granophyre occurring on the inner Enderby and East Lewis Islands. Spheroidal weathering of the igneous rocks has resulted in a highly distinctive boulder terrain, forming strike-controlled elevated hills and ridges. These are generally free of vegetation and often separated by deeply incised V-shaped gullies and/or broader valleys, which form a trellis-like drainage pattern on the granite terrain and a more dendritic-like pattern in the volcanic terrain.

Murujuga lies within a low-lying arid floodplain, flanking a broad, tidally dominated continental shelf (Figure 1). The archipelago and other islands of the North West Shelf host one of the most significant longterm records of Aboriginal symbolic and economic adaptation to fluctuating sea levels in Australia. There are an estimated 1 million engravings, numerous stone structures, middens, quarries, and other occupational remains across the archipelago (McDonald and Veth 2009). Pleistocene-aged occupation has now been recovered from the Burrup Peninsula (McDonald et al. 2018b) and at least two continental islands on the inner North West Shelf (Veth et al. 2017a, 2017b), and we predict that such sites would have occurred across similar and different geologies and features on the drowned coastal plain (Figure 2). It has been argued that on predominantly sediment-starved coastlines, such as this, submerged archaeological deposits would only tend to be preserved in special situations, such as when local landforms are protected from high energy events - for example, in the lee of islands and/or indurated under erosion-resistant strata (Erlandson 2001:327). While destructive cyclonic winds bear from the east in North West Australia and storm surges would have accompanied these events, the complex morphology of the volcanic islands likely provided localized opportunities for site preservation. Indeed, much of the Dampier Archipelago and wider North West Shelf region provides precisely these characteristics, with high-resolution bathymetric mapping showing widespread evidence of extensive well-preserved drowned shorelines and other relict coastal landscape features in the shallow waters ( $<40 \mathrm{~m}$ depth) of the inner shelf (Brooke et al. 2017; Ward et al. 2013; 2016). 


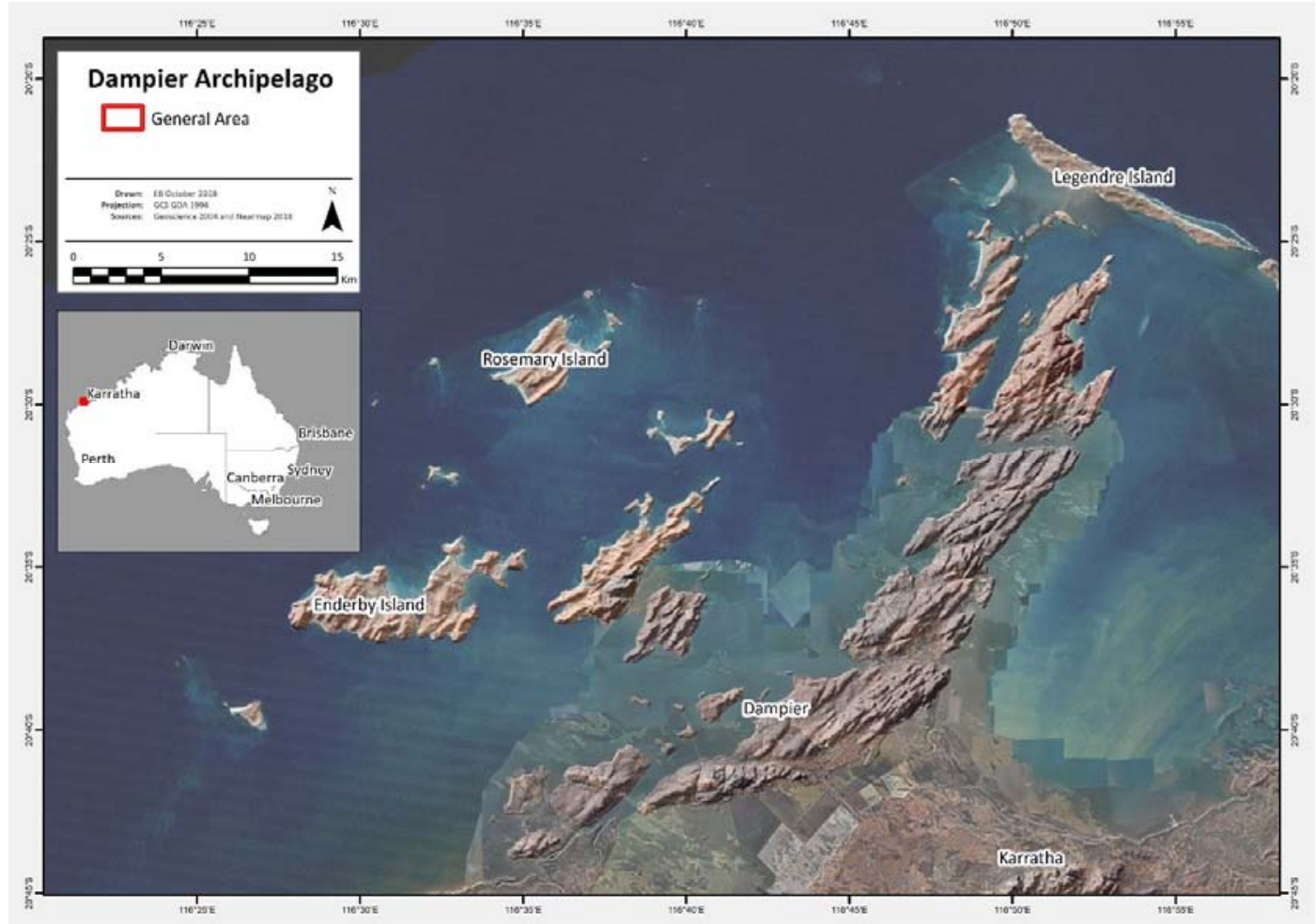

Figure 1. Location of Dampier Archipelago in North-West Australia showing 42 islands and their generally complex volcanic topography, extensive embayments and prevalent coastal and interior valleys and scree slopes (Burrup Island is connected by a causeway with salt flats to the south and Legendre Island at the north is comprised of calcarenite lacking the same degree of elevation).

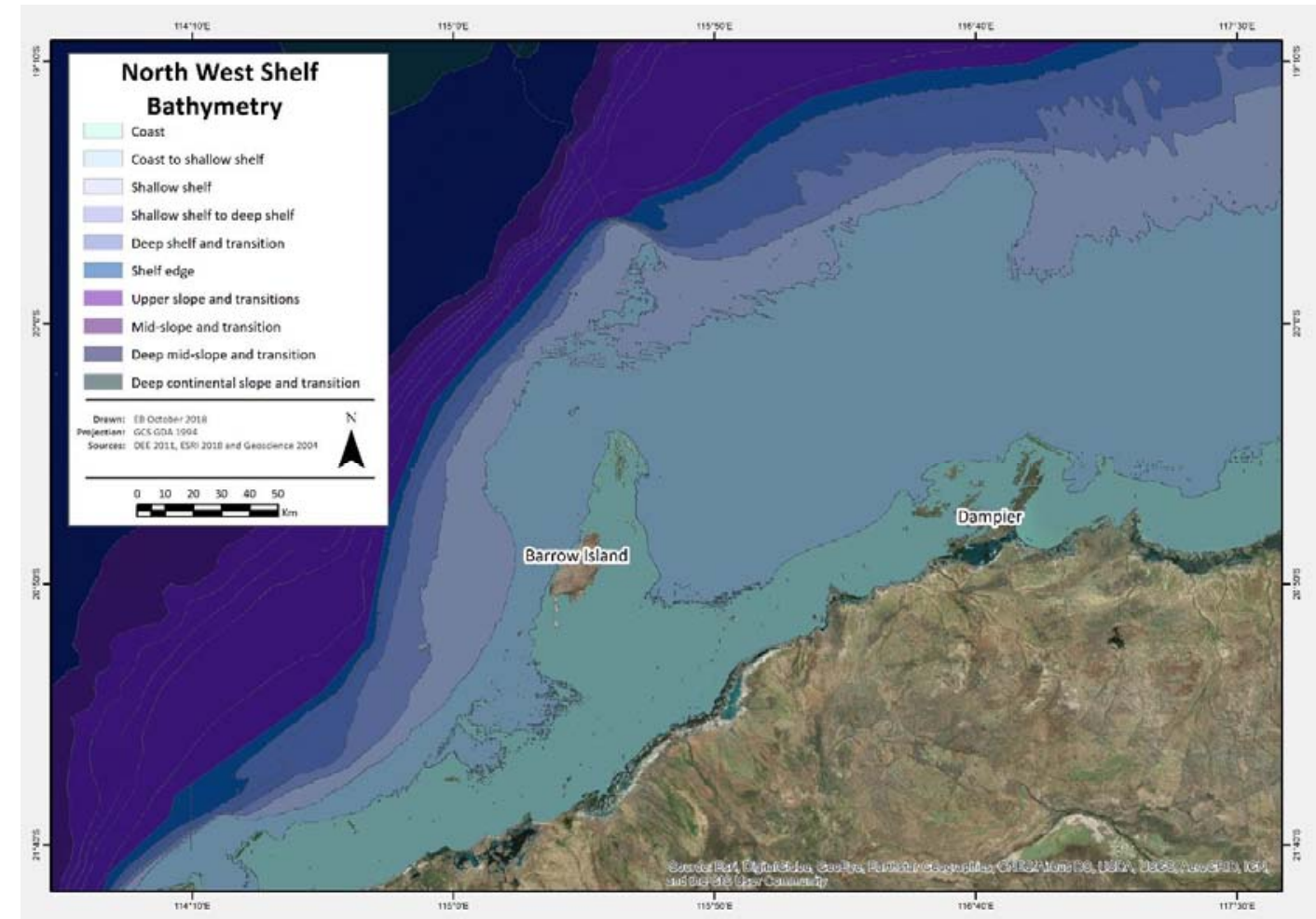

Figure 2. Location of Dampier Archipelago on the North West Shelf showing other prominent Islands and macro scale geomorphic units from interpreted or reported bathymetric divisions. 
There is a broad range of physical processes occurring at the coastline and across the shelf that are likely to have differentially impacted archaeological and associated landscape features; not least of these are the large tidal ranges, cyclones, tropical lows and associated wet-season runoff (Ward et al. 2013). Such processes have contributed to active and complex coastal dynamics, which in turn influence the coastal habitats that past people would have occupied and used (Larcombe et al. in press; Semeniuk 1994; Sullivan et al. 2011). As outlined by Semeniuk (1994), the response of these geomorphic/habitat systems to sea level rise will neither be uniform nor simple, with more heterogeneous systems of the indented (ria) shorelines, including the Dampier Archipelago, adjusting more slowly than more homogeneous systems (see also Semeniuk 2013; Ward et al. 2015). One inference from this observation is that some elements of the earlier geomorphic/habitat systems may be preserved if they have been rapidly buried during transgression. Where sea levels and coastal processes have been consistent, it is possible for more mature coastal environments to develop, including for example, coastal mangroves and fringing reefs. Thus the question of what is similar and what has changed is a fundamental one in terms of comparing onshore and offshore features and sedimentary sequences.

\subsection{Regional Archaeological Context}

Recent studies illustrate how Aboriginal people have constantly adapted to dynamic environments on the coastline from both before and after the Last Glacial Maximum (Veth et al. 2017a). Middens and macrofaunal records on Barrow and the Montebello Islands demonstrate increasing reliance on marine resources from 42,000 years ago (Veth et al. 2007, 2014, 2017b). Recent excavations in the Murujuga Rockshelter provide evidence for human occupation in the later phases of the Last Glacial Maximum, with the focus of occupation shifting away from this shelter towards the encroaching shoreline in the Late Pleistocene/early Holocene (McDonald et al. 2018b). The engravings of the Archipelago document (in part) the rising of the sea:

Most of the engravings, particularly the images of marine fauna, are slightly or moderately weathered and were produced following the rise of sea levels about 8,000 years ago. There are a number of deeply weathered images of terrestrial fauna, particularly kangaroo, which date to the time when the sea was much lower (Lorblanchet 1992). The different degrees of weathering of particular types of faunal engravings on the Dampier Archipelago provide an outstanding visual record of the course of Australia's cultural history through the Aboriginal responses to the rise of sea levels at the end of the last Ice Age (Commonwealth of Australia Gazette 2007:7; see also Mulvaney 2015).

While rock art provides a tangible link to the submerged prehistory, it is unknown whether rock art will be readily visible under water due to the masking effects that marine growth may have on both the modified and unmodified cortex. The erosion rates of these panels have been argued to be extremely slow, enhancing the longevity and visibility of older repertoire art (Mulvaney 2015; Pillans and Fifield 2014). Previously, dive surveys of granophyre rocks at depths of 10-20 m below the surface failed to reveal any engravings, but confirmed that some rock faces are free of marine growth (Dortch 2002). The only known submerged rock art site in Paleolithic Europe, found at Cosquer Cave (Clottes et al. 1992), contains very well-preserved paintings in a deep cave system where the entrance is now submerged, but the art survives above the waterline in an air pocket. No visible pigment art has been identified as surviving under water. This is salutary in terms of the prospection of submerged rock art, as preservation will be a key to site discovery. 
The Cosquer Cave gives some insight into the type of material and techniques used in that environment. Whether or not Murujuga's engraved rock art will have survived transgression remains to be investigated.

Current research efforts are focused on identifiable macro-scale site types, such as linear and stratified middens, rockshelters and overhangs, and stone arrangements, including house structures (McDonald and Berry 2016), stone arrangements used for hunting (e.g., O'Shea et al. 2014) and fishtraps (Kreij et al. 2018). All of these are durable features which may have a higher chance of withstanding the destructive effects of wave action and shallow-water currents during sea-level rise, and are of appropriate scale to be observable using remote sensing technology.

Distinction needs to be made here between 'hard rock' contexts (i.e., rock art, quarry sites, stone structures), and 'soft rock' contexts (i.e., midden sites, artifact scatters). This distinction is critical in the analogy between marine and terrestrial contexts in the assumption of 'like for like' in hard rock contexts. In contrast, soft rock contexts will be far more dependent on sedimentary processes that will have changed over time. The latter if they survive would prove informative about human resource manipulation (Astrup et al. nd; Cook Hale et al. in press; Lourandos 1997; McNiven and Ulm 2015) and potentially changing responses to coastal contexts and ecosystems (Ward et al. 2013: Table 2). While remote survey may provide some insight into location of archaeological sites in soft rock contexts, the relationship between these and any terrestrial analogues needs to be demonstrated on geological, geomorphological, and/or chronological principles through ground-truthing.

\section{DHSC Methods and Hierarchy of Actions}

The launch of the European Space Agency's two Earth Observation satellites (Sentinel-2a and 2b) in 2015 and 2017, provides for the first time open access satellite imagery, with a $10 \mathrm{~m}$ spatial resolution in the blue, green, red, NIR spectral bands. A $290 \mathrm{~km}$ field of view and 5-day return time increases the probability of capturing cloud free and clear water conditions whereby shallow ( $<10 \mathrm{~m}$ water depth) submerged landforms such as paleo-shorelines and lagoons, dune fields, rocky shoals and allied features can be identified. By combining the Sentinel satellite imagery with maritime charts (to provide additional bathymetric information of deeper water areas), it becomes possible to identify specific paleo-landforms which have a higher probability of hosting macro-scale site types.

These target areas are then mapped at a higher resolution using a bathymetric Light Detection and Ranging (LiDAR) device (Riegl VQ820G), which produces a high-density point cloud of seabed features. LiDAR's ability to map the seabed is limited by water quality with high levels of turbidity and sea state (i.e., white caps), limiting the ability of the LiDAR's green laser to penetrate the water column. During typical calm, clear water conditions it is possible to map the seabed to a depth of $15 \mathrm{~m}$ and up to $40 \mathrm{~m}$ (Fugro LADS) below sea level (depending on the type of instrument used). The high-density point cloud generated by the laser scanner can produce a modelled elevation grid with a spatial resolution from $25 \mathrm{~cm}$ (VQ820G) to $3.5 \mathrm{~m}$ (Fugro LADS), with the potential to capture middens, fishtraps, and other features which exhibit vertical relief above the sea bed. The real utility of airborne LiDAR is the ability to map large areas particularly within shallow nearshore environments that are relatively inaccessible to ship-mounted survey instruments. 
The highest level of resolution and mapping depth is provided by a sidescan sonar (Edgetech 4125), which can provide ultrahigh resolution imagery of the sea floor over a relatively large swath area (10 $\mathrm{m}$ to $200 \mathrm{~m})$ depending on water depth and pulse frequency used. The imagery generated can capture targets having a relatively small surface area and/or relief above the sea bed. Thus, once a macro-scale site type is identified, sidescan technologies can be used to locate cultural features such as stone circle arrangements, standing stones, artifact scatters and similar that can then be targeted for ground-truthing. The assumptions for predicting submerged sites and their geological contexts, the general methods deployed to conduct remote sensing and direct survey, and the final questioning of what links terrestrial and submerged sites and their contexts is outlined in Figure 3.

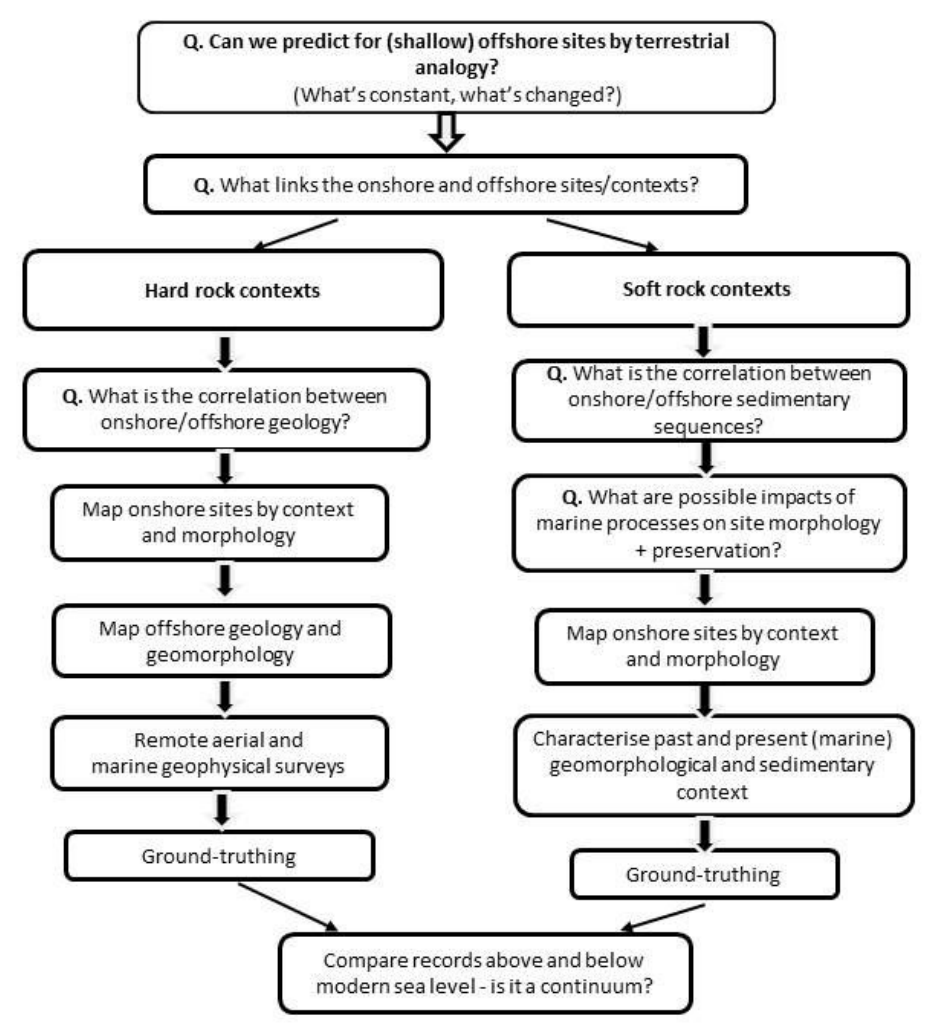

Figure 3. Flowchart of the assumptions for predicating submerged sites.

\section{Patterning of Archaeological Sites and Chronology from Murujuga - Towards Predicting Site Types for Directing Underwater Surveys}

The human use of marine resources through deep time over the larger North West Shelf has been documented by survey and excavation on continental limestone islands such as the Montebello Islands and Barrow Island - the latter at $204 \mathrm{~km} 2$ - representing the second largest island off the Western Australian coast (Veth et al. 2007, 2017a). Occupation evidence shows the movement of raw materials for artifacts across the vast coastal plains from the interior from $50 \mathrm{ka}$ until abandonment c. 8-7 ka. At this time the islands became too distant for watercraft travel $(>50 \mathrm{~km})$ from the mainland (Veth et al. 2017a). There are four species of dietary shellfish in Boodie Cave from before $40 \mathrm{ka}$ and the number of species expands significantly to over 40 when the coast becomes proximal. Intriguingly Terebralia sp. mangrove molluscs 
from the terminal Pleistocene units suggest that the coastline was comparatively productive well before stillstand and that these and other species were carried inland by up to an estimated $15 \mathrm{~km}$ distance (Manne and Veth 2015; Veth et al. 2017b). While occupation is not registered during the LGM, this may be due to groups being more closely tethered to a productive Pleistocene coastline and to interior ranges such as the Murujuga uplands (McDonald et al. 2018a).

The Dampier Archipelago has one of the highest concentrations of Indigenous sites recorded in Australia (JMcDCHM 2006; Veth et al. 1994; Vinnicombe 2002) and these cover a wide range of features and artifact types. The high site density has been attributed to the proliferation of symbolic and economic archaeological evidence (JMcDCHM 2005, 2006; McDonald 2015; McDonald and Veth 2009), due to:

1) the human refugium-effect of the highly dissected and scree-sloped granophyre and gabbro uplands both when they were located 10 s through to 100 s of kilometers inland from the former coastal zone;

2) the slowly eroding nature of the fine-grained crystalline rocks and their ability to preserve most engraving actions; and

3) the seasonal abundance of coastal marine resources in this location.

In the assessment of the Archipelago's scientific values for National Heritage Listing, a sample of 2,534 sites was analyzed (JMcDCHM 2006). Over 60\% of these are engraving complexes (many combined with other site types); some 14\% have artifact scatters and modified stone structures (e.g., pits, standing stones, lines, circles and terraces); $2.5 \%$ quarry and reduction areas; and $2.1 \%$ shell middens and grinding patches. The very high site densities have been recorded from a range of research, mitigation, and heritage management surveys (see summary by McDonald 2015). Approximately $50 \mathrm{~km} 2$ of the Burrup Peninsula and inner islands has received some level of recording with overall densities within specific survey areas of up to 45.6 sites per km2 (range 17-254 sites km2) and petroglyph densities of 26.0 per km2 (1.2-218 sites km2). Given that not all surveys were intensive or involved saturation coverage (i.e., they were $<100 \%$ in their coverage) these figures are considered to be under-estimates of actual site density.

A range of predictive statements have been developed for site occurrence across landform units, catchments and islands (e.g., JMcDCHM 2006; McDonald 2015; Veth et al. 1993; Vinnicombe 2002). The landforms and features identified in previous reports having the most site categories and highest site densities include:

1) Coastal and interior valleys with semi-permanent water;

2) Flat coastal pavements and outcrops flanking mangroves and sandy bays;

3) Dunes and sand bodies flanking embayments; and

4) Granophyre and basalt substrates and especially finer-grained outcrops. 
The Murujuga uplands were initially located in the arid interior (pre-7 kya) and are now part of a coastal desert system (post-7 kya). The coordinated drainage systems host ephemeral springs, seasonal rock holes, wells and sumps with associated high floristic and faunal diversity where higher site numbers and clustering are expected (O'Connor and Veth 1993, 2000; Veth et al. 2007, 2014, 2017b). The added productivity of proximal marine resources between 10-7 kya is expressed in an early-to-mid Holocene stratified record within the coastal and interior valleys and associated uplands (Dortch et al. 2017; McDonald and Berry 2016; Veth et al. 2017b). Figure 4 is based on site data from the National Estate Grants program (NEGP) surveys (Veth et al. 1994), The National Heritage Listing Report (JMcDCHM 2006), surveys of Deep Gorge (JMcDCHM 2009), from the UWA Rio Tinto Iron Ore annual rock art field schools, and the current Murujuga: Dynamics of the Dreaming ARC Linkage Project (https://researchimpact.uwa.edu.au/researchimpact-stories/murujuga-dynamics-of-the-dreaming/). This illustrates the highest site densities across those areas which have been surveyed. The heat map shows that some of the highest site densities (across the combined categories of engravings, shell/artifact scatters, and stone features) occur within the coastal and interior valleys, associated uplands, and larger embayments.

Transect surveys of Deep Gorge, Rosemary, and Enderby Islands confirm the focus on these landforms (Figure 5-8; CRAR+M 2018; additional sources cited in figures). Survey coverage of the outer islands has been skewed towards identifying and recording engravings: the Deep Gorge survey systematically recorded all site types in detail. Across the broader archipelago, high relief ridges, scree slopes, and sometimes sheersided gorges provide both optimal habitation loci with semi-permanent water, economically useful plants, and fuel timber and also numerous panels for engravings. These boulder surfaces and rock platforms are also excellent for vegetable processing/grinding activities (Reynen and Morse 2016).

Figure 9 shows the distribution of geology and varying site densities from surveyed areas. More than twothirds (67\%) of (largely, rock art) sites occur on the granophyre and basalt substrates, likely reflecting more intensive habitation and associated engraving actions on optimal panels and vantage points. We believe there is a similar potential for past engraving, grinding, and quarrying behaviors to have occurred on similar panels, boulders and vantage points in, what is now, the marine context. The potential for engravings being discovered underwater, however, will be affected by marine growth, and potentially also the disintegration of the hard outer crusts of the rocks when submerged. While crystalline (volcanic) rocks comprises more than two-thirds of the surface geology on the Archipelago, and with which $67 \%$ of sites are associated, they may represent less than $10 \%$ of the exposed or shallow buried submerged geology around the archipelago.

Middens (scatters, linear and mounded) are common across the archipelago and have now been dated back to the time of initial eustatic inundation between > 10 kya to 6 kya (Bradshaw 1995; Dortch et al. 2017; McDonald and Berry 2016). Midden excavations reveal an earlier dominance of the mangrove shellfish Terebralia palustris (e.g., Bradshaw 1995; Clune 2002; Lorblanchet 1976, 1977, 1978, 1983; McDonald et al. in prep.; Vinnicombe 1987). Where these earlier Terebralia sp. deposits have been discarded in significant quantities and are expressed on the surface, they are usually subdued $(<1 \mathrm{~m})$ in height. 


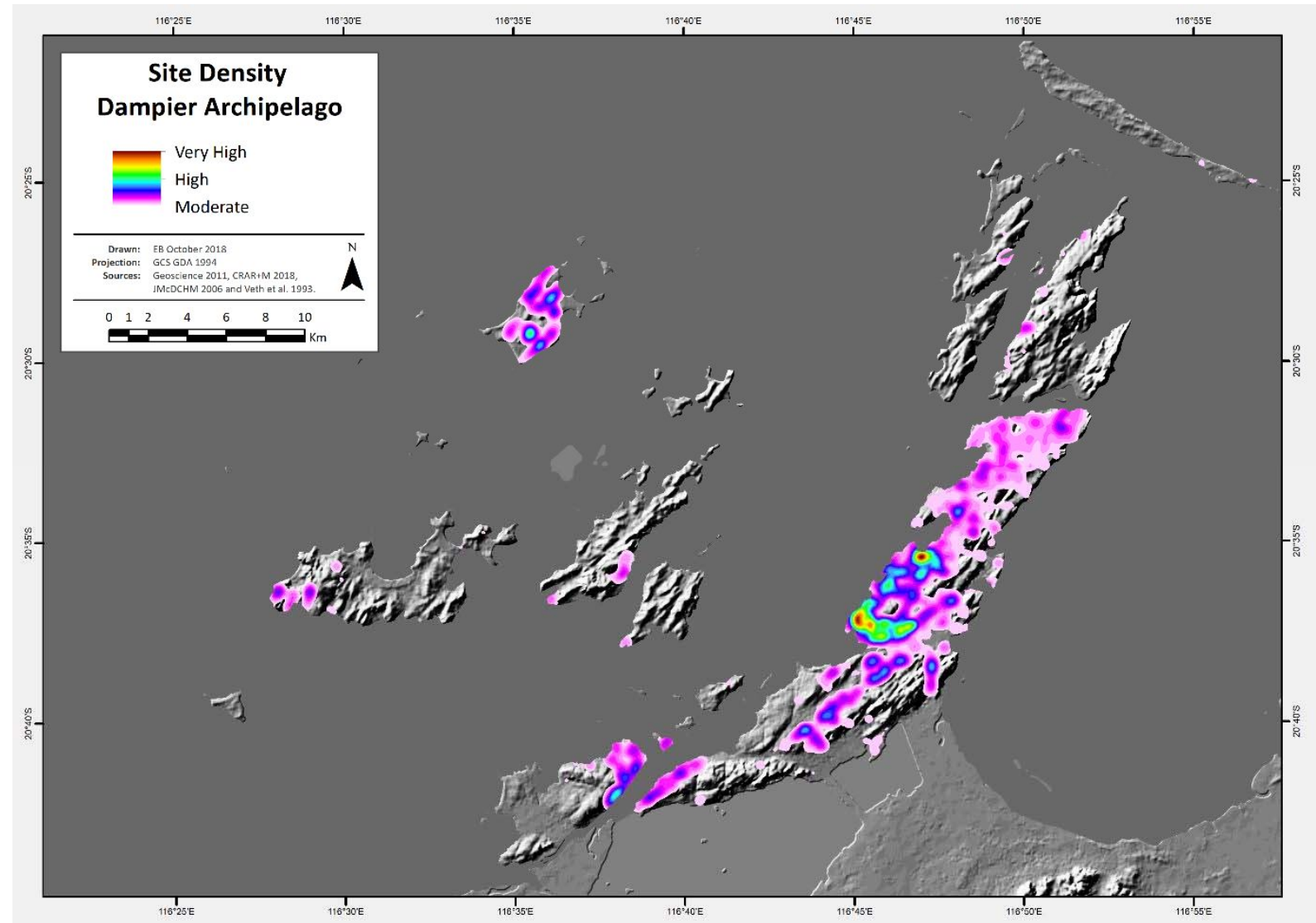

Figure 4. Some comparative site densities across landforms of the Archipelago where surveys have occurred; these vary from reconnaissance to systematic survey for engravings to intensive-mode 'hot spots' on the Burrup where more systematic recording has been undertaken of all features. Note there have only been partial or reconnaissance surveys over many catchments on the Burrup, proximal and outer islands - therefore these heat maps are heuristic devices only. 

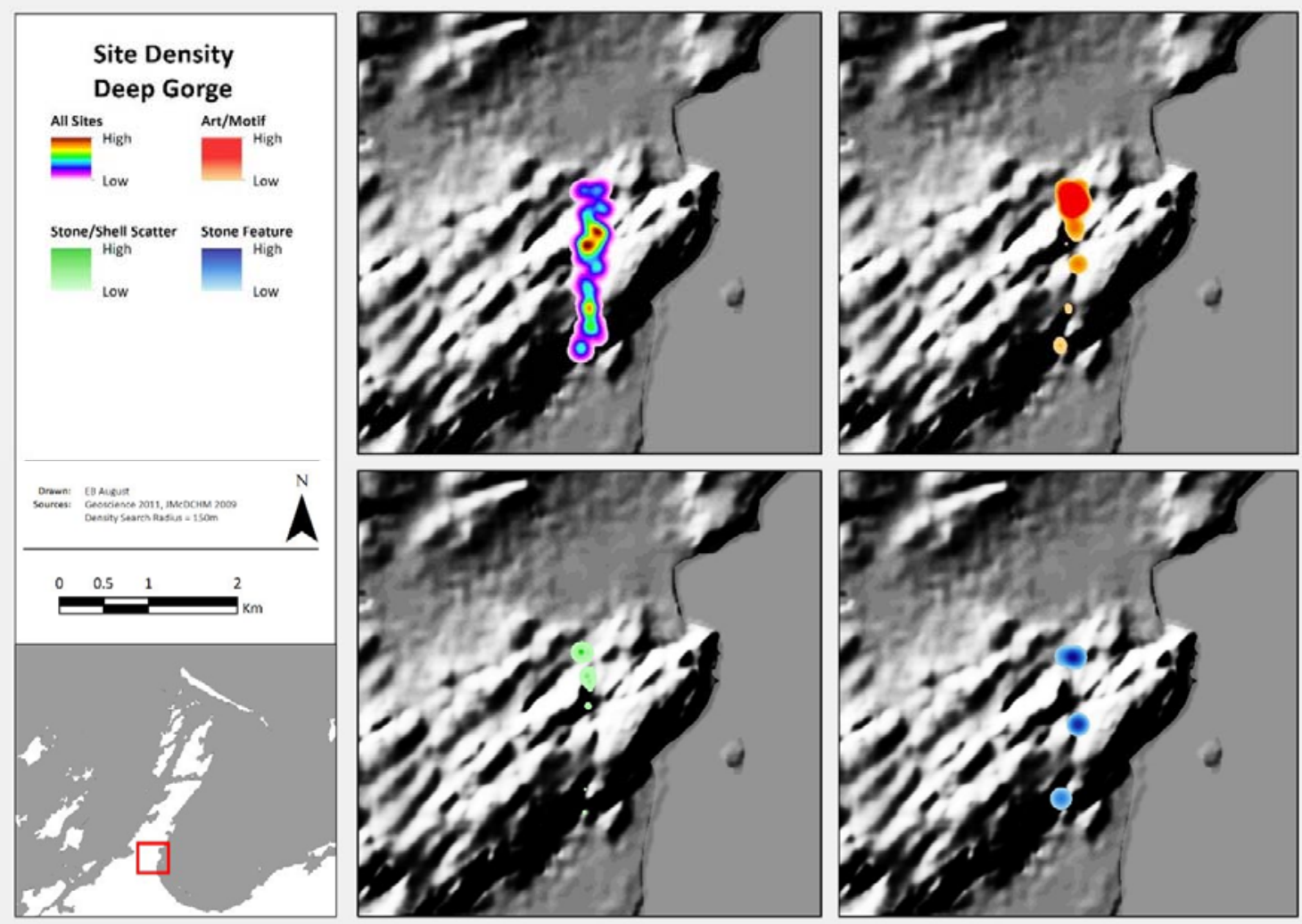

Figure 5. Indicative site densities for Deep Gorge by broad site categories
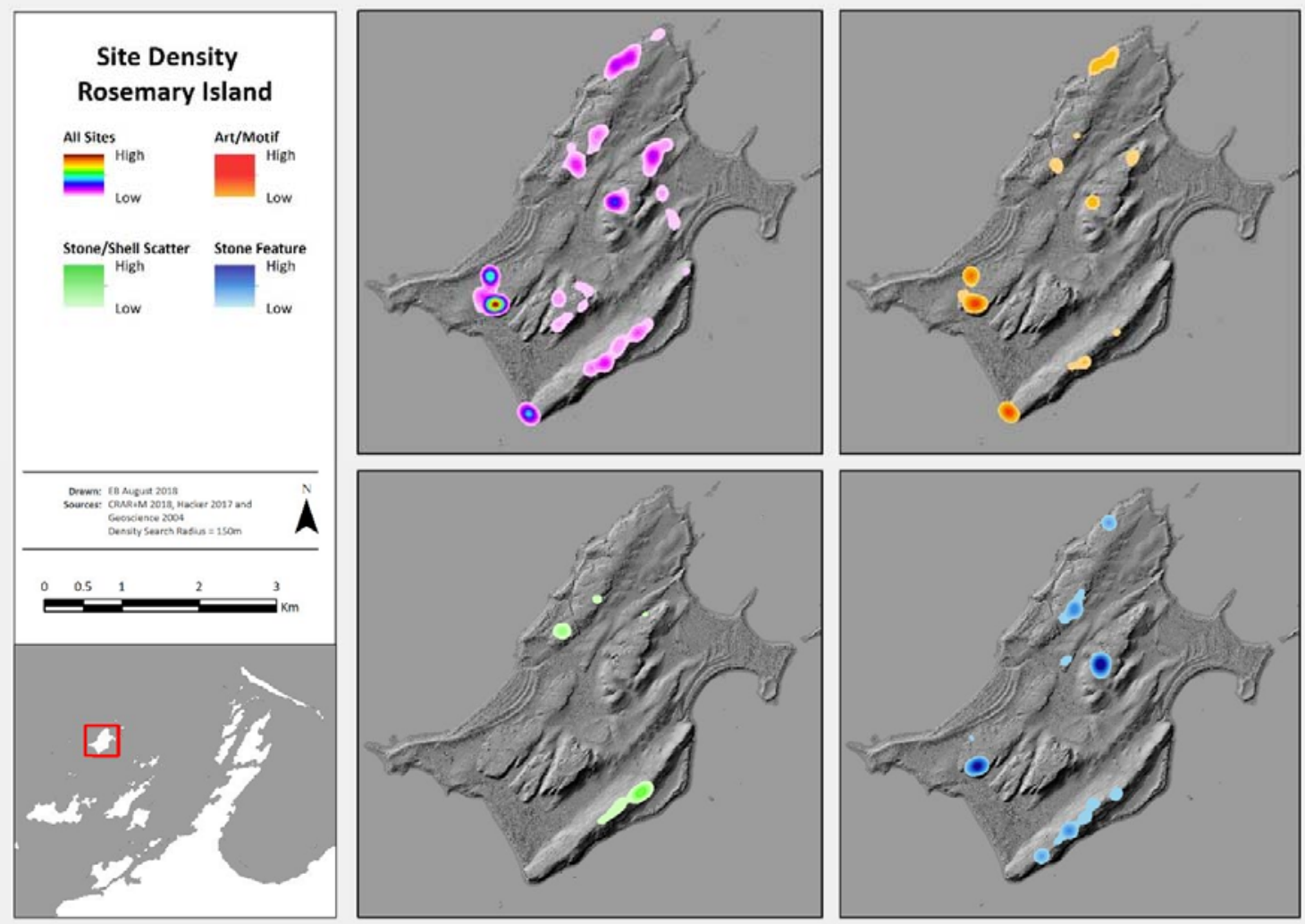

Figure 6. Indicative site densities for Rosemary Island by broad site categories ( targeted transect survey). 


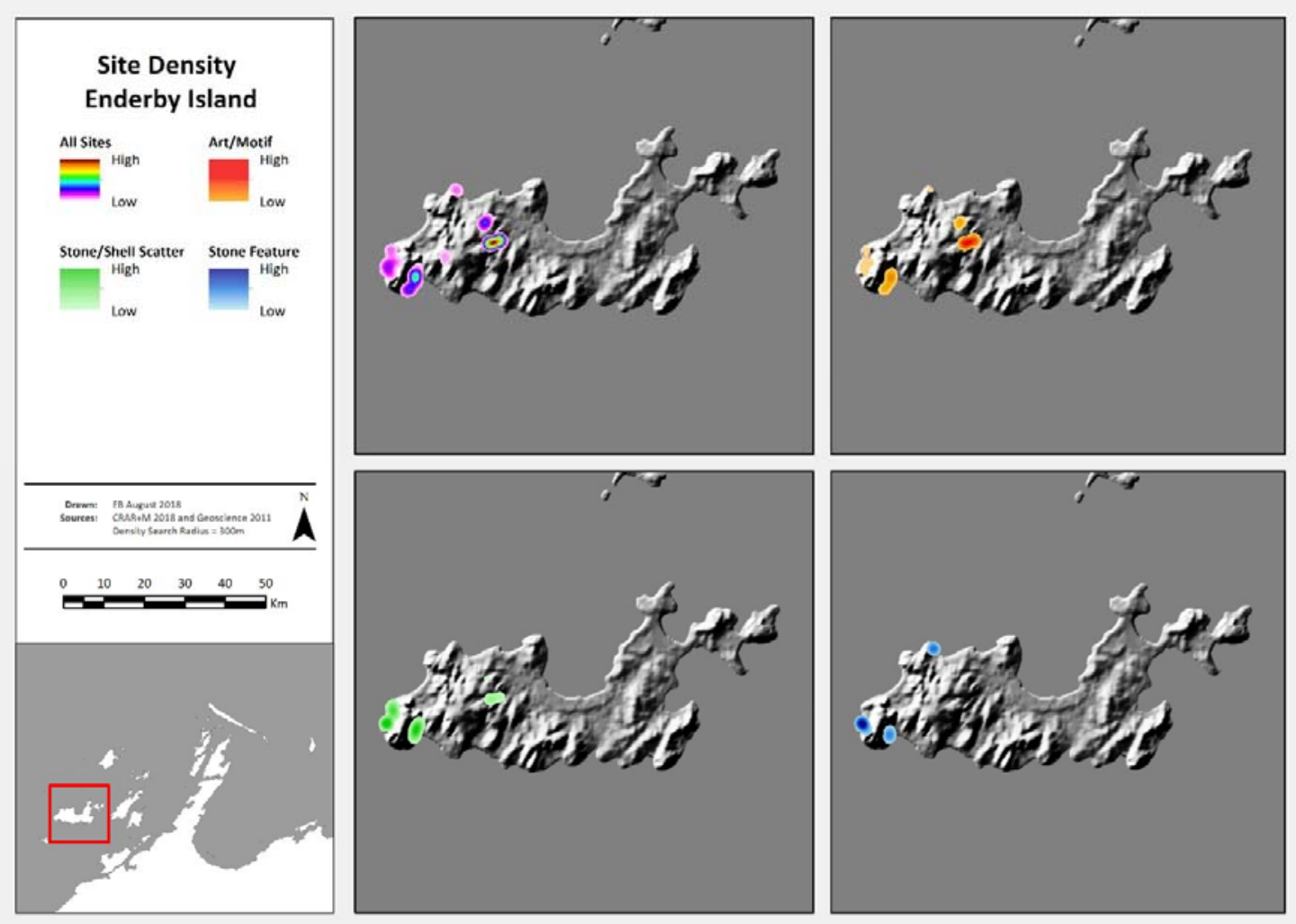

Figure 7. Indicative site densities for Enderby Island by broad site categories (for transect surveys of six sample areas at the western end of the Island)
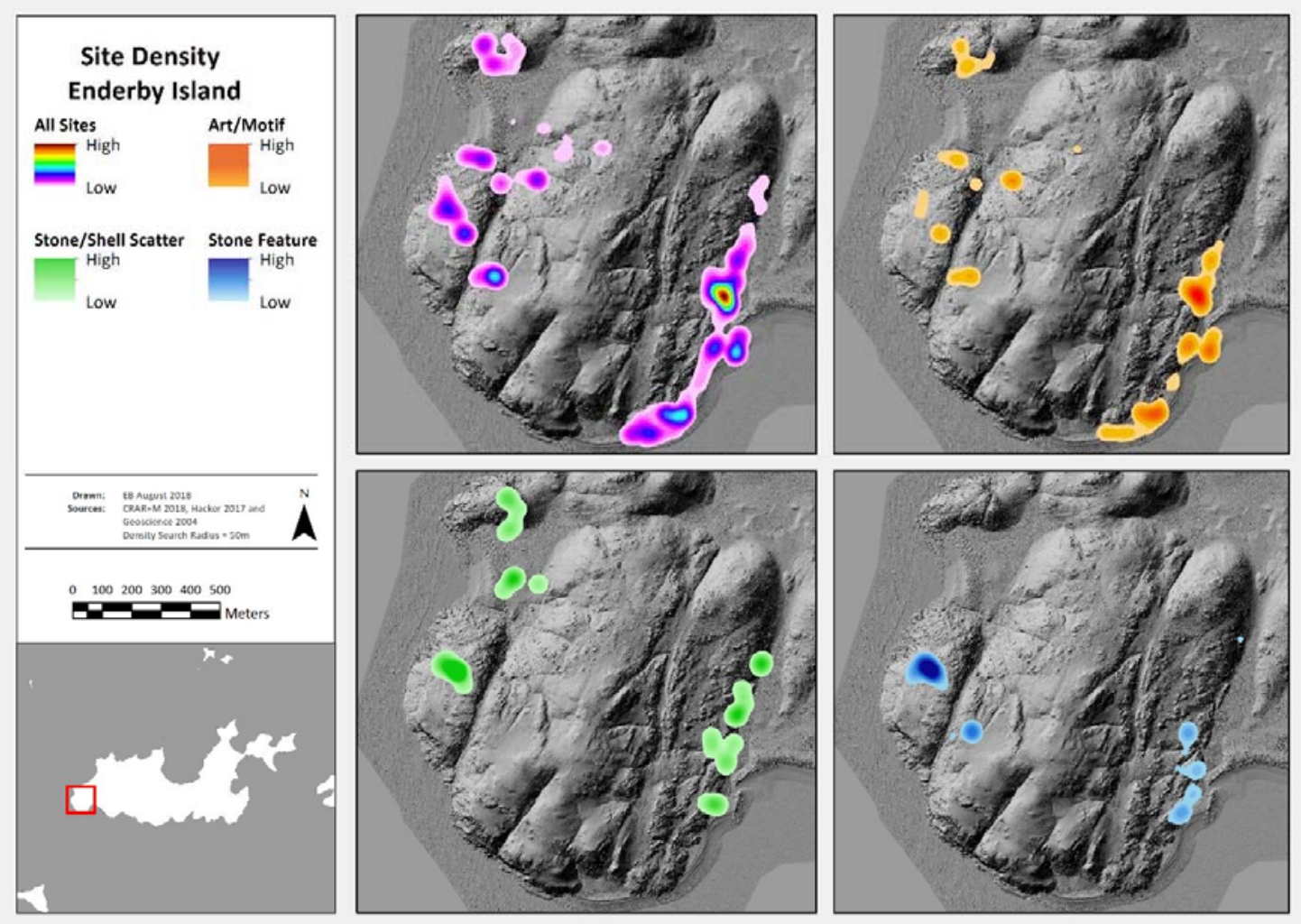

Figure 8. Indicative site densities for the southwest promontory of Enderby Island by broad site categories overlain on Lidar hill shade mapping 


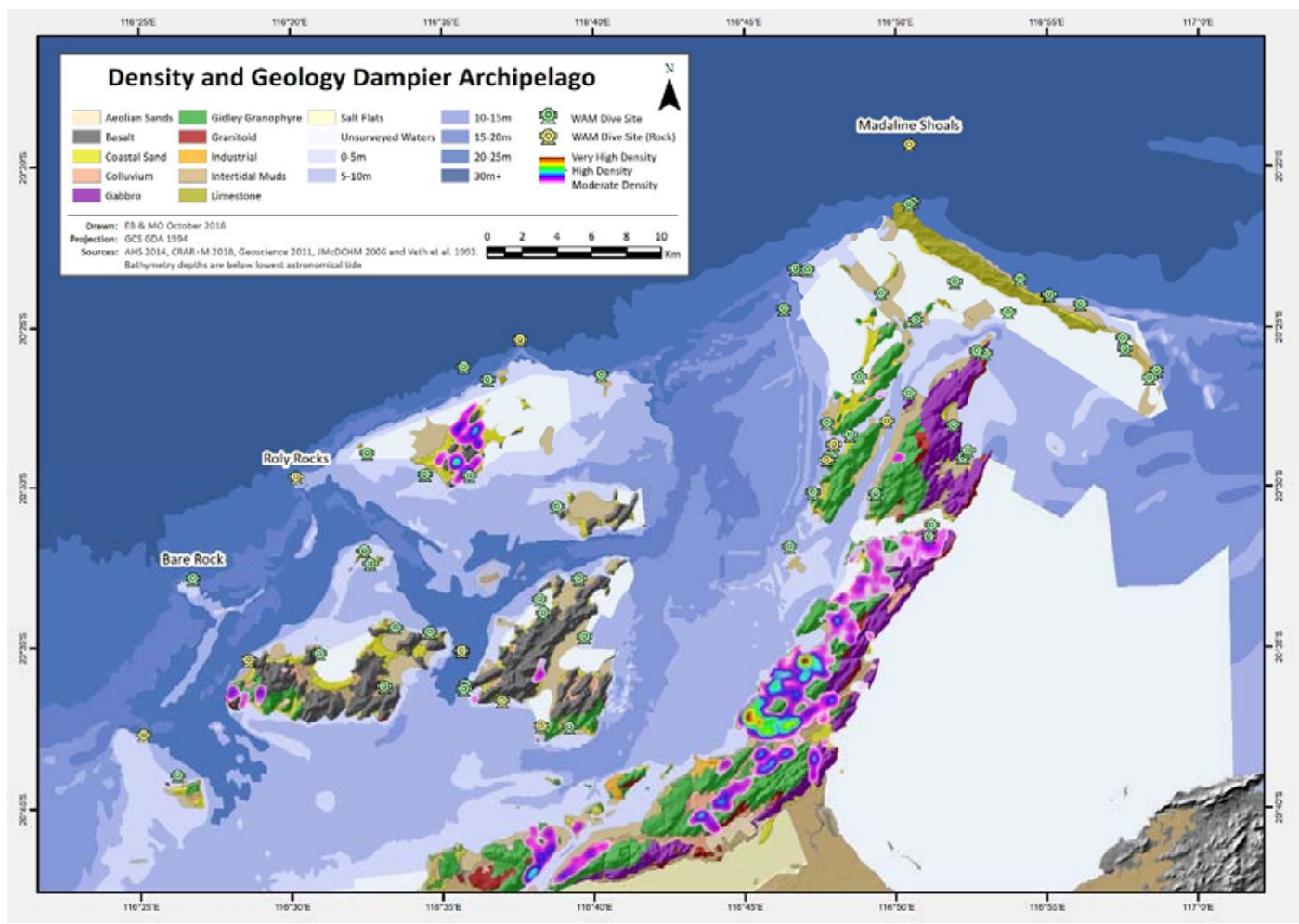

Figure 9: Geology and bathymetry of the Dampier Archipelago showing submerged rocks and shoals in the range of 5 to $30 \mathrm{~m}$ below sea level. These likely represent extensions of the Gidley Granophyre and Basalt substrates to the north and west.

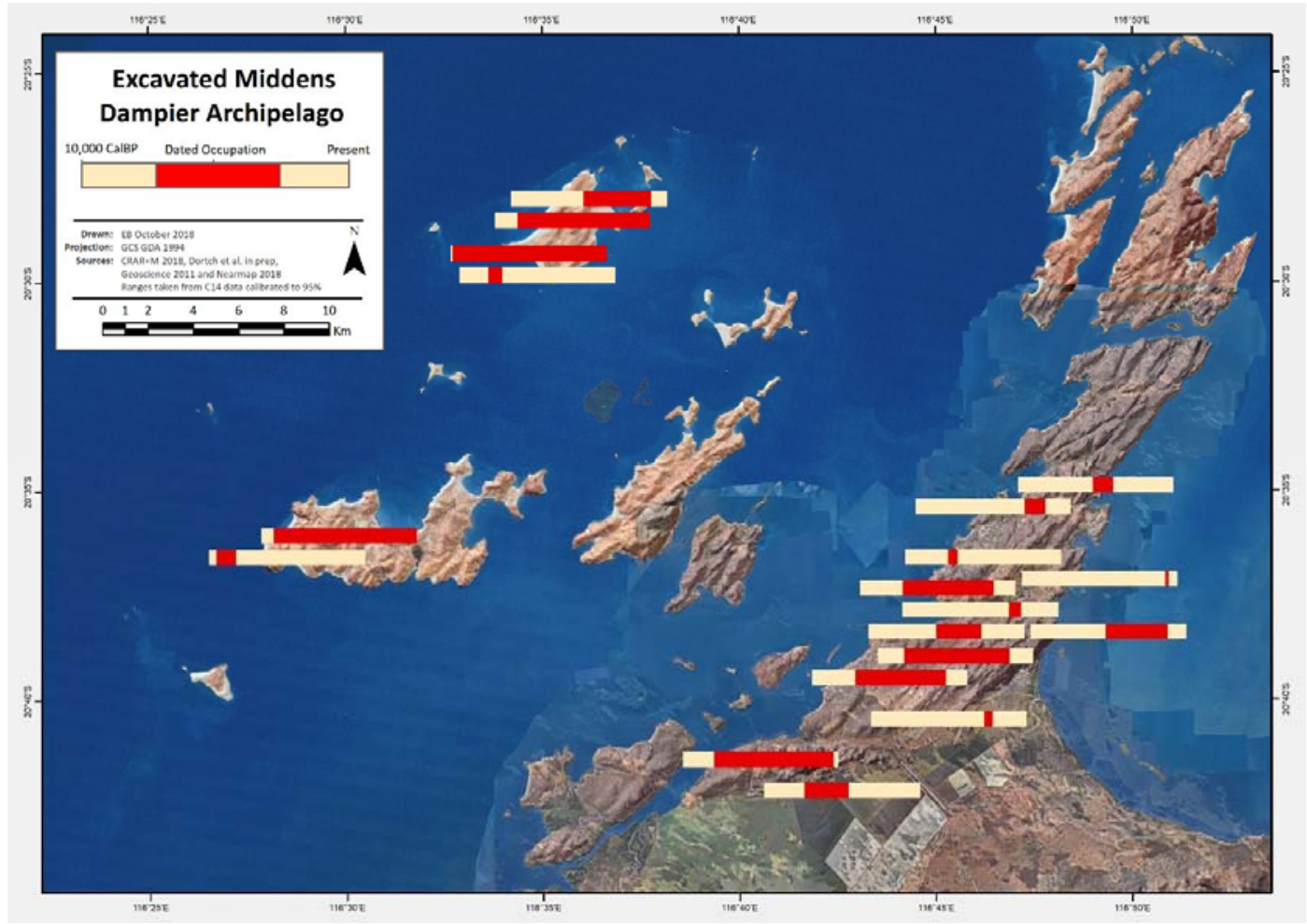

Figure 10: Bar charts showing approximate ages for excavated sites on Murujuga using the max and min $95 \%$ calibrated age. $10 \mathrm{ka}$ bar is read from left (oldest) to right (present). Red shows dated midden while tan shows when sites cease to be occupied. 
Such features have been found on Rosemary Island where shallow (c. $30 \mathrm{~cm}$ deep) stratified middens are associated with stone circle complexes, often lying on rocky pavements. One such stone feature and a nearby Terebralia midden have been dated to between 8063 and $7355 \mathrm{cal} \mathrm{BP} \mathrm{(McDonald} \mathrm{and} \mathrm{Berry} \mathrm{2016).} \mathrm{The}$ Rosemary 8 site has a raised and cemented midden deposit around a rock hole with calcium carbonate encrustation as well as seven circular structures sitting on a hard pavement and Terebralia midden deposits within these. These are the earliest dated domestic structures in Australia and have been interpreted as evidence for the demarcation of social space in response to sea level rise and loss of land (McDonald and Berry 2016). Such structures may be prominent enough to be detectable underwater and may preserve early Holocene Terebralia units with stratigraphic integrity.

Recent middens dating to the last 4000 years reveal more localized environmental sequences with either Tegillarca granosa (formerly Anadara) or a range of rocky foreshore species becoming dominant (Bradshaw 1995; Lorblanchet 1992; McDonald and Berry 2016). Changes in shellfish species after approximately 4 kya are argued to be linked to changing shoreline ecology (Bradshaw 1995; Harris 1988). Some of these larger shellfish discard mounds, such as those on West Intercourse Island and Nickol River, provide clear evidence for the repeated collection, processing, and discard of key marine species (shellfish, crustacean and fish) in association with rock art production. Importantly they have appreciable elevation (e.g., over 5 meters in height) that may allow detection through remote sensing, assuming that they have survived intact the potentially deflating effects of marine erosion. The conundrum is that none of the early Holocene middens surviving on land today have appreciable elevation, making them harder to detect underwater. This raises the need to target indurated deposits, drowned shorelines, and features such as stone arrangements, which may have potentially entrapped stratified deposits. There are many known carbonate deposits (e.g., seepage, indurated breccia, beach rock, travertines, etc.) throughout the archipelago with several travertine features around rock holes recently cored, but as yet unanalyzed.

Large granophyre quarries such as those recorded in King Bay (Veth 1982) and more recently at the western end of Enderby Island (Figure 8), have been observed to contain numerous extraction pits measuring several meters across and sometimes more than a meter deep. Large boulders, decortification flakes, and debris are mounded around the lips of some of these features and again, like the habitation structures, they have the potential to be targeted in remote sensing and underwater survey. The combination of circular stone structures with stratified midden and quarry/extraction areas on two outer islands (Rosemary and Enderby) provides known and obvious targets on inundated areas sharing the same geology.

In our last fieldwork period undertaken this year, we located a stone artifact scatter in the inter-tidal zone on Dolphin Island (Dortch et al. nd). We intensively surveyed ca. $6000 \mathrm{~m} 2$ in the intertidal zone (Dortch et al. nd), recording more than 75 large artifacts in these sample areas. Additional artifacts were seen outside the sample areas, but not yet recorded. To characterize landform, visualize the artifact distribution, and better understand site formation processes, we flew two sets of drone transects. These were flown at low tide at altitudes of 30 and $50 \mathrm{~m}$, resulting in images with a ground sample distance of between 1-1.5 cm/pixel with $75 \%$ front overlap (i.e., in direction of drone travel) and $65 \%$ side overlap (between transects) to produce an ortho-rectified photomosaic with $1.43 \mathrm{~cm} /$ pixel resolution and a digital elevation model (DEM) at 5.74 $\mathrm{cm} /$ pixel resolution (Dortch et al. $\mathrm{nd}$ ). We are further investigating this site using Lidar and side-scanning sonar, and propose to use diving to further explore and record the submerged extent of this site. 
The Montebello and Barrow Island records and recent reviews of the Carnarvon bioregion dates (Veth et al. 2014) show there is repeated occupation with evidence for exploitation of an increasing range of marine resources, as well as a broad suite of arid zone terrestrial prey, in the period from 12-10 kya, where the shoreline would have been located within several kilometers (Ward et al. 2013). This is seen to mark the onset of proximal marine resources, which we have argued would be incorporated regularly within the economy of maritime desert foragers systematically using the sub-coastal zone (Veth et al. 2017a). The outer islands of the Archipelago register middens and associated features by ca. $10 \mathrm{kya}$, well before the inner islands; and these in turn are older than most sites with marine resources on the present-day mainland where near-high stand occurs by ca. 7-6 kya. The cline in stratified midden dates from outer to inner islands with decreasing bathymetry (Figure 10) matches the larger regional patterns of the North West Shelf (Veth et al. 2014).

\section{Remote Sensing Program - Creating Targets from Underwater Data}

Locating submerged macro-scale site types first requires the identification of the landform and/or environment they are associated with. One approach is to apply remote sensing methods to the task, which can provide a measure of geomorphic change at the land system scale. Here this involves the collection, analysis, and interpretation of bathymetric terrain data, collected using a range of satellite, airborne, and shipboard instrumentation, the specifications of which will typically vary around: 1) spatial footprint and resolution; 2) water column penetration; and 3) raster image or vector point cloud data collection formats.

Paleo-landforms that were present or formed on the continental shelf during the span of last glacial cycle (80 to 10 thousand years BP), and were subsequently submerged during postglacial sea level rise, are presently situated at depths of between 10 to $125 \mathrm{~m}$ below present sea level. Brooke et al. (2017) were able to identify a range of paleo-shoreline features related to persistent (modal) sea levels centered in particular between 30 to $40 \mathrm{~m}$, and also 50 to $60 \mathrm{~m}$, and 70 to $80 \mathrm{~m}$ below present, but these are beyond the depth of some remote sensing technologies, such as LiDAR and certainly too deep for the proposed research diving surveys. Within the Dampier Archipelago, lithified dune, beach, and offshore bar deposits rim the outer islands at about $20 \mathrm{~m}$ depth (Figure 11). Other remnant or relict coastal landforms may have been modified through erosion or possibly even preserved by burial during Holocene sea level transgression, although again there are examples where Holocene paleoshoreline features do survive in shallow waters (e.g., Ward et al. 2016). Understanding the formation and role of inherited features within the broader coastal geomorphic framework is unfortunately beyond the scope of this study. These features do at least provide a likely focal point for human occupation, archaeological site preservation, and investigation of changing landform dynamics. As such, our seabed mapping efforts are focused at more shallow depths, firstly locating coastal landscape features, then identifying specific coastal landforms based on feature morphology and association between features. 


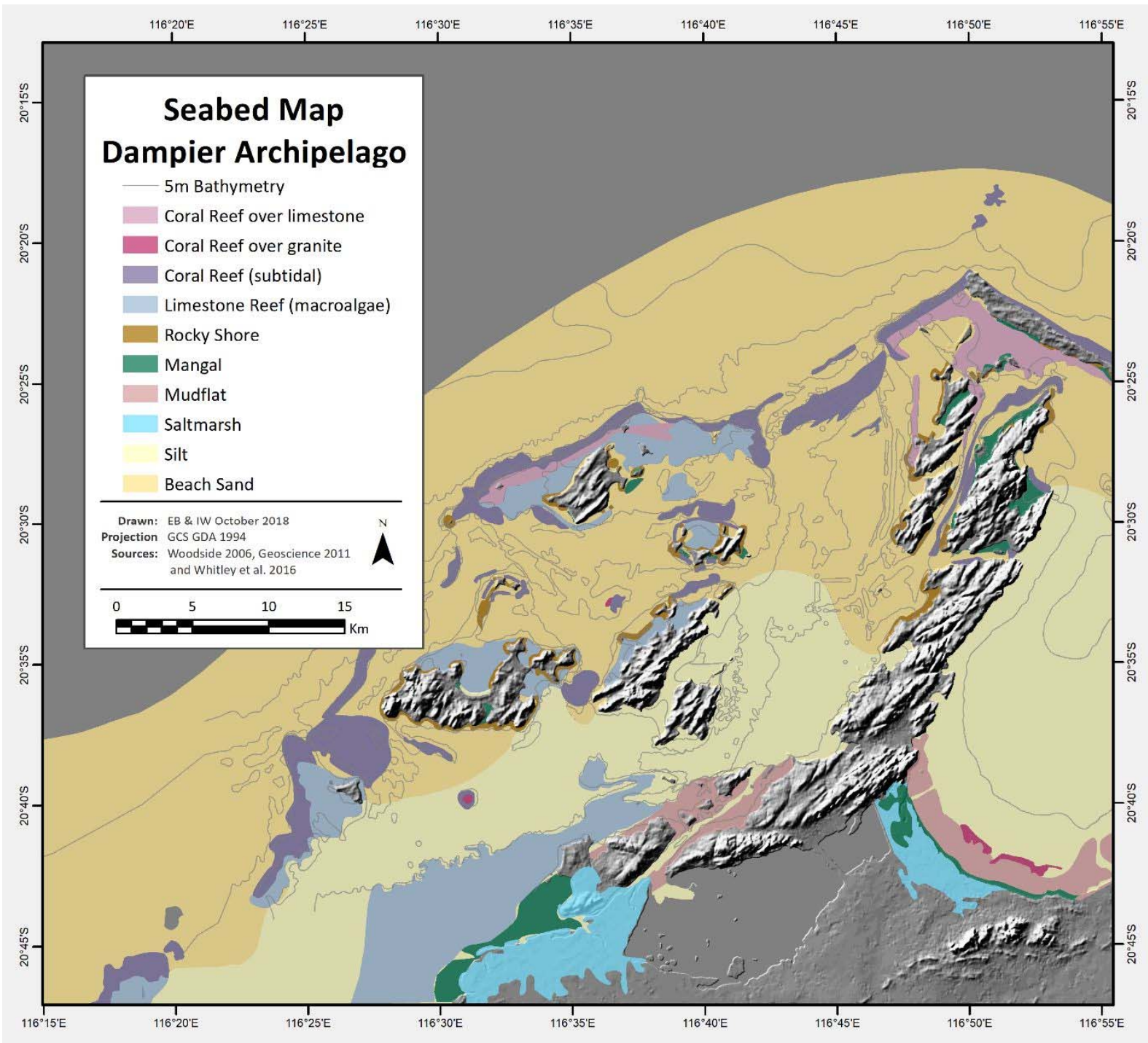

Figure 11. Bathymetry and geomorphology of seabed within $10 \mathrm{~km}$ of Dampier Archipelago. 


\subsection{Preliminary Results}

Recent mapping by remote sensing of the Dampier Archipelago has highlighted the utility of each of Sentinel satellite, airborne bathymetric Lidar, and sidescan sonar instruments for locating prospective landforms in and around this region. Analysis of Sentinel satellite imagery taken during periods of particularly high-water clarity, low wave, and low tide conditions has allowed the identification of a series of submerged beach barrier shorelines that extend north from Bare Rock to Roly Rock and south from Bare Rock to North West Reefs (Figure 9), across the northern entrance to Mermaid Sound. The tops of these beach barrier shorelines sit between 5 and $10 \mathrm{~m}$ below sea level and likely represent a sea level still stand at 15 to $20 \mathrm{~m}$ below present sea level.

Bathymetric LiDAR mapping has captured most of the shallow water seabed environments in and around the Dampier Archipelago down to a maximum depth of $15 \mathrm{~m}$ and has clearly defined shallow reef and shoal environments, submerged paleokarst environments, and coastal and shallow subtidal rock formations (Hacker 2017). The ultrahigh resolution sidescan sonar has been able to capture with high fidelity, fine-scale sea bed features that would otherwise go undetected; these include rocky alluvial fan deposits which extend from the coast and into the shallow subtidal zone. The sidescan was also able to identify small rock formations and structures along the outer edge of the archipelago which are too deep (i.e., below $15 \mathrm{~m}$ ) for the LiDAR to pick up.

\section{Using Terrestrial Site Patterning to Scope Potential Underwater Sites}

\subsection{Scoping Location of Underwater Sites}

It is premature in this paper to generate a zoned sensitivity map for site potential on the submerged landscapes of the archipelago as remote sensing, post-survey processing of LiDAR, and confirmation of drowned geology is still in progress. It is possible, however, to scope several high potential areas and use these as a heuristic device to target further side scan, coring and diver ground-truthing surveys. This approach is consistent with our aim in this paper of outlining the strategy for assessing the continuity of terrestrial and maritime landscapes across Murujuga (and see Benjamin et al. 2018).

The following are the most frequent and visible terrestrial sites that, if surviving inundation, might be detected underwater due to their recognizable form or association with geomorphic features:

1) Midden and artifacts within cemented dunes and beach rock deposits and around calcium carbonate encrusted waterholes on identified paleo-creek lines;

2) Quarry outcrops, extraction pits and associated reduction debris;

3) Circular and curvilinear stone structures on pavements with associated midden;

4) Standing stones on platforms and in boulder piles;

5) Lag deposits of artifacts on hardpan outer island landscape features and in the intertidal zone along protected waterways of the inner islands; and 
6) Small overhangs and shelters with preserved deposits.

Figure 9 shows geology and bathymetry for Murujuga and submerged rocks and shoals in the depth range of 5 to $30 \mathrm{~m}$, which have been identified and logged by Western Australian Museum research divers. The Dampier Archipelago represents the westernmost extent of the Pilbara Cratons and seaward of the archipelago the seafloor is characterised by a broad gently seaward sloping shelf, which is mantled by a veneer of marine carbonate and/or relict siliciclastic sediments. Carbonate reefs and shoals represent areas of positive topographic relief above the seabed while Pleistocene age paleoriver channels represent areas of negative topographic relief. Based on the onshore record, and in targeting culturally prospective submerged sites, one target comprises areas that contain boulder fields with a degree of vertical relief above the sea bed. Granophyre boulder fields might be considered highly prospective. An example of one such prospective site is the Madeline Shoals, located 3 to $5 \mathrm{~km}$ north of Cape Legendre in the Dampier Archipelago. The Dampier Archipelago maritime chart (AHS, 2014) identifies a further two distinct shoals in this area; both rise from a seabed depth of around $35 \mathrm{~m}$ with the tops of the shoals located in approximately $15 \mathrm{~m}$ water depth. A single dive survey of the Madeline Shoals by the Western Australian Museum describes the feature as consisting of a "massive igneous monolith, sloping steeply on all sides; shallower areas with some hard coral, but mostly soft corals and gorgonians in deeper areas, bottom siltier with many sea whips" (WA Museum field notes; Figure 12 and Figure 13 show a similar shoal at Roly Rocks). Interestingly, the location of the Madeline Shoals north of Cape Legendre is situated on the same SW-NE striking trend as the Gidley Granophyre units located on Angel and Gidley Islands, located to the immediate west of Dolphin Island. Therefore, the Madeline shoals are more likely to be comprised of granophyre rather than gabbro or basalt. Such an area could hypothetically preserve remnants of stone arrangements or secondarily deposited artifacts from occupation contexts.

A second example is the shoal area to the north of Enderby Island and within the NNW trending paleoshoreline feature, which may have occupational deposits within the lee of this barrier. Returning to the simplified notion of the two principal variables needed for site discovery: the site must have been occupied (formed initially) and must be preserved today. A leeward side of a natural breakwater or barrier has been shown to have preserved stabilised material, even in exposed environments, and in some cases the natural breakwaters may themselves be submerged, though shallower than the cultural material they shelter. This is the case in Israel, where submerged indurated dune systems weaken the impacts of winter storms and shelter the suite of well-preserved Neolithic material near shore (e.g. Galili and Rosen 2011). Submerged sinkholes are also good examples of a natural harborage where cultural deposits may stabilise and remain preserved while winter storms break on the naturally forming barriers, such as in the case at Zambratija Bay, Croatia (Benjamin et al. 2011a; for North American examples, see also Dunbar et al. 1992; Halligan et al. 2016). Thus, a sheltered, leeward side of a depression, where transgression would have been gentler and modern impacts of cyclones and other storms are lessened, are desirable targets and therefore prioritized. 


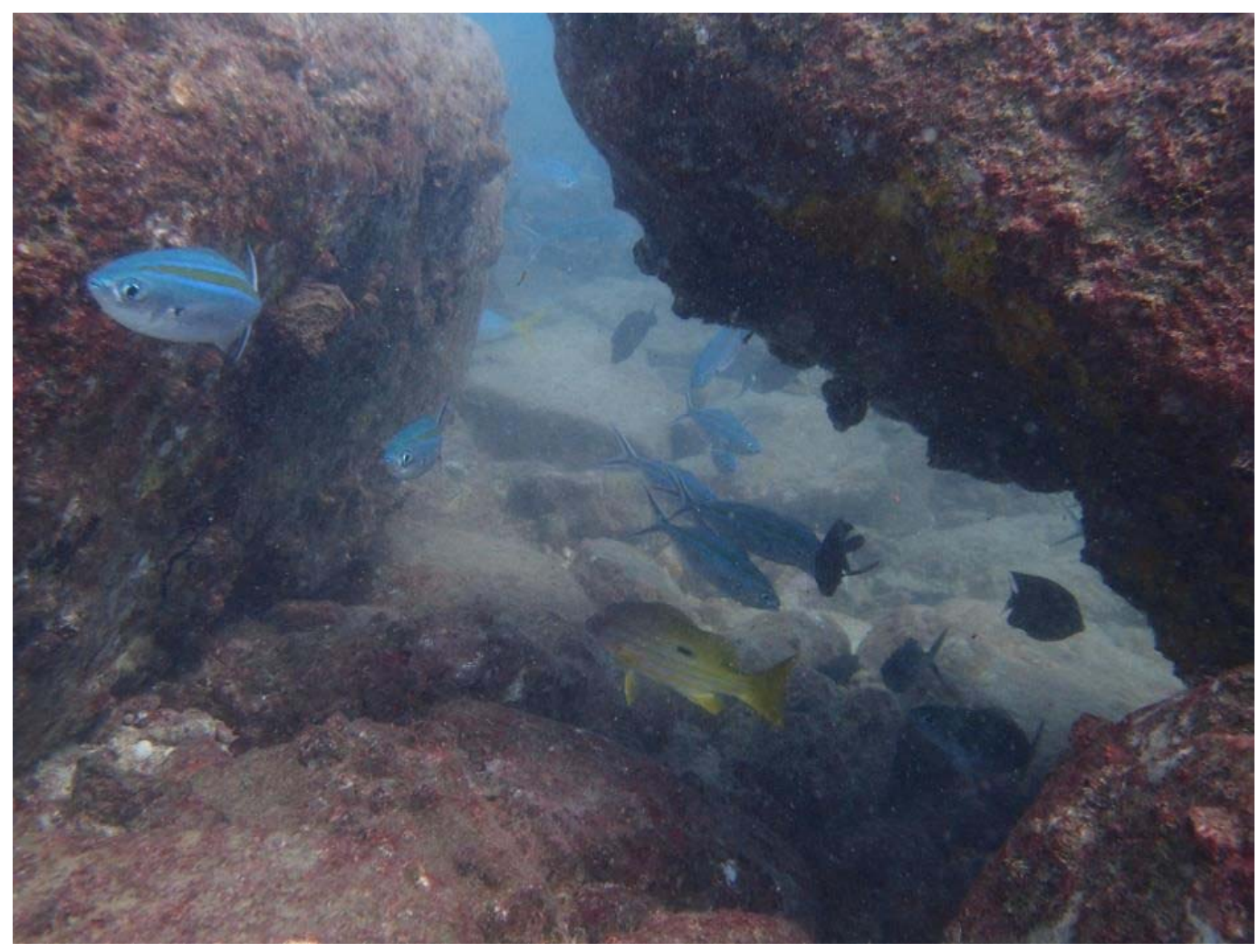

Figure 12. An example of the current underwater conditions at Roly Rocks (Photo by Zoe Richards, WA Museum).

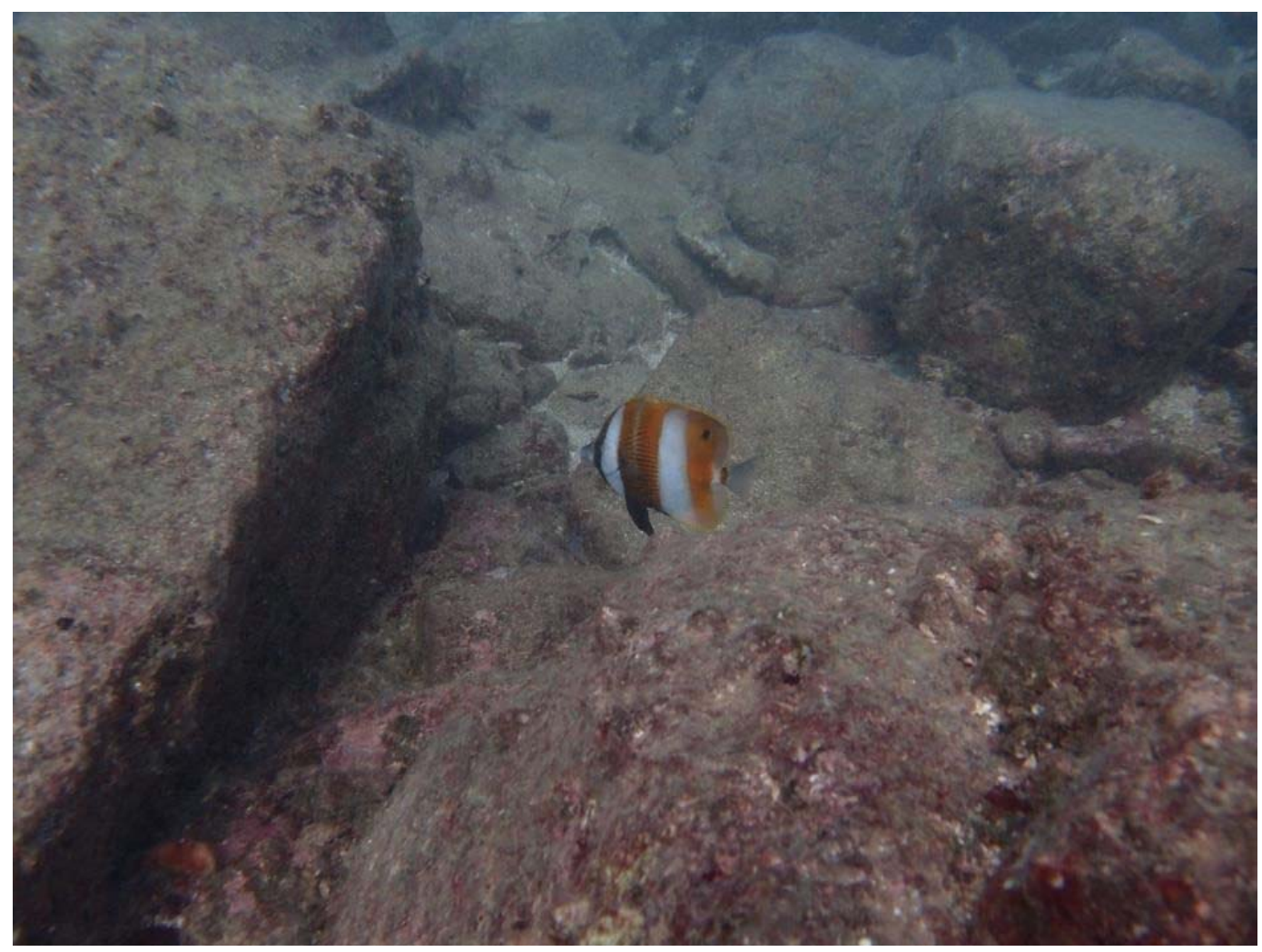

Figure 13. An example of the current underwater conditions at Roly Rocks (Photo by Zoe Richards, WA Museum). 


\subsection{Advantages and Limitations of the Terrestrial Analogy Approach}

The large number of sites $(>2,500)$ previously recorded for Murujuga, as well as those $300+$ sites recorded during the current terrestrial surveys for the Murujuga: Dynamics of the Dreaming project provide clear spatial patterning due to repeated human behaviors. This terrestrial record suggests that now-drowned cultural remains for the North West Shelf will also have patterning. The regional record of sites excavated from continental islands with terminal Pleistocene-early Holocene dietary and utilitarian shellfish and lithics transported across the now-drowned Shelf (Veth et al. 2017a), combined with the first presence of middens from 10 kya on the outer islands of Murujuga, indicate that the inner North West Shelf has been occupied for at least ten millennia and should have some site categories represented.

Site patterning from terrestrial to submerged contexts may well not be analogous due to differing geological suites, topography and marine sedimentary processes. Taphonomic and other natural transforms could have resulted in the majority of sites being destroyed with sea level rise. While terrestrial and bathymetric LiDAR and side-scan sonar theoretically have the potential to show sub-meter features, such as stone arrangements and mounds with cultural matrix, there are many natural features that can mimic cultural ones (e.g., spinifex circles on land and corals underwater).

While acknowledging these limitations, work carried out in advance of the expansion of the Rotterdam harbour demonstrates that analysis of bathymetry and geology combined with acoustic survey can be used to identify submerged landscape features such as ancient shorelines and sand dunes thought to be likely attractors of human settlement at depths of c. $20 \mathrm{~m}$ (Moree and Sier 2015). Coring of these target areas demonstrated the presence of cultural material in some locations, and this was followed up with industrialscale excavation and sieving of large volumes of sediment that recovered Mesolithic artifacts and fauna from several locations dated at ca. $9500 \mathrm{BP}$.

In the absence of marine core data to assess geomorphological change in and around the islands of the Dampier Archipelago, or of the changing physical processes affecting sedimentation, our analogy of onshore and offshore contexts is mainly limited to hard rock sites that are less likely to have moved significantly (although cyclones and tsunamis are capable of moving large boulders). Targeted coring work is required to assess marine sedimentary processes, particularly in areas with prolific site signatures on the islands.

\section{Conclusions}

We have developed a strategy for assessing both the potential and limitations of transposing site patterning, context, and sedimentary processes from terrestrial to submerged contexts. There are likely highly specific and localized requirements for site deposition, survival through inundation, and long-term preservation in a submerged context on the North West Shelf. Although the likelihood of site survival in this sediment-starved and periodically high energy subtropical setting may be low, we endorse a strategic approach that considers both natural and cultural formation processes through time.

Remote sensing using data from the European Space Agency's two Earth Observation satellites (Sentinel-2a and $2 b$ ), in combination with maritime charts, has allowed the identification of shallow submerged landforms 
such as paleoshorelines and lagoons, dune fields, rocky shoals, and allied features. Some of these landforms have a higher probability of hosting the categories of site types documented from the terrestrial portions of the Archipelago. Higher definition of the seabed features (from $3.5 \mathrm{~m}$ to $25 \mathrm{~cm}$ ) has been achieved through bathymetric LiDAR (RIEGL VQ820G) and laser scanning (Fugro LADS). Finally, sidescan sonar (Edgetech 4125 ) is providing ultrahigh resolution of the seabed over swaths of 10 to $200 \mathrm{~m}$. The imagery generated can detect targets with small $(<20 \mathrm{~cm})$ features such as stone circle arrangements, standing stones, mounds, and artifact scatters.

The submerged landscapes of the Dampier Archipelago have considerable potential for providing evidence of changing coastal configurations and early maritime adaptations. The occupation records associated with an earlier and now-drowned landscape may provide unique insights into settlement behavior and resource scheduling unparalleled by the extant terrestrial record. However, success in locating such evidence will depend both on the preservation of sediments and geomorphic features of the type described above during and after inundation, and on the targeting of these features by past human activity in the first place.

We predict that the following combinations of geomorphic context and archaeology form the most prospective targets:

1) Midden and artifacts within cemented dunes, relict water holes, and beach rock deposits;

2) Quarry outcrops, extraction pits, and associated reduction debris in fine-grained volcanic outcrops;

3) Circular and curvilinear stone structures and standing stones sitting on volcanic pavements and jammed into volcanic rock piles;

4) Lag deposits of artifacts and possibly midden on hardpan in suitable landscape contexts with good preservation conditions (e.g., shallow declination shorelines in sheltered passages of the inner archipelago or on the leeward side of hard-rock/fringing reef causeways adjacent to the outer islands); and

5) Small overhangs and shelters with preserved deposits, facing away from the dominant wave and wind action.

We are pursuing a multi-staged strategy for assessing the possible continuity of terrestrial and maritime landscapes in Murujuga and aim to identify the location of potential submerged cultural sites and features. A critical precondition is terrestrial site patterning through time based on a large sample of dated middens and occupation sites; ongoing consideration of marine processes and surviving contexts; and then targeted survey at various scales deploying remote sensing, diving, and coring. This strategy will optimally test for the presence, distribution, and survival of pre-inundation archaeology in Murujuga as a proof of concept with the goal of rectifying the long-standing neglect of the prehistoric archaeology of Australia's submerged continental shelf. 


\section{Acknowledgements}

We are grateful for the support of the Circle of Elders advising the Murujuga Aboriginal Corporation (MAC), and for the advice of Peter Jeffries (MAC CEO) and Sean McNeair (Murujuga Land and Sea Unit Manager). The Deep History of Sea Country project is supported by the Australian Research Council's Discovery Projects scheme (DP170100812), led by Jonathan Benjamin and with CI's Peter Veth, Jo McDonald, Michael O'Leary, Geoff Bailey, Sean Ulm; PI Jorg Hacker and Ingrid Ward (postdoctoral Fellow), and Peter J. Ross (PhD candidate). Additional support comes from the ARC Linkage project Murujuga: Dynamics of the Dreaming (LP140100393), led by Jo McDonald, with CI Peter Veth and Emma Beckett (PhD candidate). Field data was collected by the Murujuga: Dynamics of the Dreaming field teams. GIS mapping and figure preparation was done by Emma Beckett. We thank Zoe Richards for the underwater photos (Figures 12 and 13), and Joe Dortch and Sarah de Koning for assistance with ongoing preparation of data used in the illustrations.

\section{References}

Astrup, P.M., S. Ulm, C. Skriver, J. Benjamin, I. Ward, F. Stankiewicz, P. Ross, J. McCarthy, P. Baggalay, and G. Bailey. nd. Underwater shell middens: Excavation and remote sensing of a submerged Mesolithic shell midden at Hjarnø, Denmark. Submitted paper.

Australian Hydrographic Service (AHS). 2014. AUS 57 Australia North West Coast - Western Australia Dampier Archipelago. Marine Chart. Wollongong: Commonwealth of Australia.

Bailey, G.N., M.H. Devès, R.H. Inglis, M.G. Meredith-Williams, G. Momber, D. Sakellariou, A.G.M. Sinclair, G. Rousakis, S. Al Ghamdi, and A.M. Alsharekh. 2015. Blue Arabia: Paleolithic and underwater survey in SW Saudi Arabia and the role of coasts in Pleistocene dispersal. Quaternary International 382:4257.

Bailey, G., J. Harff, and D. Sakellariou (eds.). 2017. Under the Sea: Archaeology and Paleolandscapes of the Continental Shelf. Cham: Springer.

Bailey, G., N. Galanidou, H. Joens, F. Lueth and H. Peeters (eds.). In press. The Archaeology of Europe's Submerged Landscapes. Cham: Springer.

Bates, M.R., Bates, C.R. and Briant, R.M., 2007. Bridging the gap: a terrestrial view of shallow marine sequences and the importance of the transition zone. Journal of Archaeological Science 34: 1537-1551.

Benjamin, J., C. Bonsall, C. Pickard and A. Fischer (eds.). 2011a. Submerged Prehistory. Oxford: Oxbow Books.

Benjamin, J., L. Bekic, D. Komso, I.K. Uhac and C. Bonsall. 2011b. Investigating the submerged prehistory of the eastern Adriatic: Progress and prospects. In Submerged Prehistory (J. Benjamin, C. Bonsall, C.

Pickard, and A. Fischer, eds.): 193-206. Oxford: Oxbow Books.

Benjamin, J., M. O’Leary, I. Ward, J. Hacker, S. Ulm, P. Veth, M. Holst, J. McDonald, P.J. Ross, and G. Bailey. 2018. Underwater archaeology and submerged landscapes in Western Australia. Antiquity 92(363):e10. https://doi.org/10.15184/aqy.2018.103.

Bird, M.I., R.J. Beaman, S.A. Condie, A. Cooper, S. Ulm, and P. Veth. 2018. Paleogeography and voyage modeling indicates early human colonization of Australia was likely from Timor-Roti. Quaternary Science Reviews 191:431-439. https://doi.org/10.1016/j.quascirev.2018.04.027. 
Bradshaw, E. 1995. Dates from archaeological excavations on the Pilbara coastline and islands of the Dampier Archipelago, Western Australia. Australian Archaeology 41:37-38.

https://doi.org/10.1080/03122417.1995.11681559.

Brooke, B.P, S.L. Nichol, Z. Huang, and R.J. Beaman. 2017. Paleoshorelines on the Australian continental shelf: Morphology, sea-level relationship and applications to environmental management and archaeology. Continental Shelf Research 134:26-38. https://doi.org/10.1016/j.csr.2016.12.012.

Bynoe, R., Dix, J.K. and Sturt, F., 2016. Of mammoths and other monsters: Historic approaches to the submerged Paleolithic. Antiquity 90(352):857-875. https://doi.org/10.15184/aqy.2016.129.

Cassen, S., A. Baltzer, A. Lorin, J. Fournier, and D. Sellier. 2011. Submarine Neolithic stone rows near Carnac (Morbihan), France : Preliminary results from acoustic and underwater survey. In Submerged Prehistory (J. Benjamin, C. Bonsall, C. Pickard, and A. Fischer, eds.): 99-110. Oxford: Oxbow Books.

Centre for Rock Art Research and Management (CRAR+M). 2018. CRAR+M Database - MLP Data. Shapefile and Dataset. Accessed 24/06/18. https://www.crarm.com.au/

Chapman, H.P. and M.C. Lillie. 2004. Investigating 'Doggerland' through analogy: The example of Holderness, East Yorkshire (UK). In Submarine Prehistoric Archaeology of the North Sea: Research Priorities and Collaboration with Industry (N.C. Flemming, ed.): 65-69. CBA Research Report 141. York: Council for British Archaeology.

Clarkson, C., Z. Jacobs, B. Marwick, R. Fullagar, L. Wallis, M. Smith, R.G. Roberts, E. Hayes, K. Lowe, X. Carah, S.A. Florin, J. McNeil, D. Cox, L.J. Arnold, Q. Hua, J. Huntley, H.E.A. Brand, T. Manne, A. Fairbairn, J. Shulmeister, L. Lyle, M. Salinas, M. Page, K. Connell, G. Park, K. Norman, T. Murphy, and C. Pardoe 2017 Human occupation of northern Australia by 65,000 years ago. Nature 547(7663):306-310. https://doi.org/10.1038/nature22968.

Clottes, J., A. Beltrán, J. Courtin, and Henri Cosquer. 1992. The Cosquer Cave on Cape Morgiou, Marseilles. Antiquity 66(252):583-598. https://doi.org/10.1017/S0003598X00039314.

Clune, G. 2002. Abydos: An Archaeological Investigation of Adaptations on the Pilbara Coast, Northwest Western Australia. Ph.D. Dissertation. Perth: University of Western Australia.

Commonwealth of Australia Gazette. 2007. Environment Protection and Biodiversity Conservation Act 1999-Inclusion of a Place in the National Heritage List. Gazette Special. No. S127.

Cook Hale, J.W. and E.G. Garrison. 2018. Spatial statistical analysis of coastal plain Paleoindian site distributions and paleoecology: Implications for the search for offshore submerged sites in Georgia. Early Georgia 45(1-2):167-180.

Cook Hale, J.W. N.L. Hale, and E.G. Garrison. In press. What is past is prologue: Excavations at the Econfina Channel site, Apalachee Bay, Florida, USA. Southeastern Archaeology.

https://doi.org/10.1080/0734578X.2018.1428787.

David, B., J-M. Geneste, R.L. Whear, J-J. Delannoy, M. Katherine, R.G. Gunn, C. Clarkson, H. Plisson, P. Lee, F. Petchey, C. Rowe, B. Barker, L. Lamb, W. Miller, S. Hoerlé, D. James, É. Boche, K. Aplin, I.J. McNiven, T. Richards, A. Fairbairn, and J. Matthews. 2011. Nawarla Gabarnmang, a 45,180 \pm 10 cal BP Site in Jawoyn Country, Southwest Arnhem Land Plateau. Australian Archaeology 73:73-77. 
Deeben, J., Hallewas, D.P. and Maarleveld, Th.J., 2002. Predictive modelling in archaeological heritage management of the Netherlands: the indicative map of archaeological values ( $2^{\text {nd }}$ Generation). Berichten van de Rijksdienst voor Oudheidkundig Bodemonderzoek 45: 9-57.

Department of the Environment and Energy (DEE). 2011. Bathomes within Australian waters. Shapefile. Canberra: Geoscience Australia, Department of Industry, Tourism and Resources. Last Modified 1/4/2011 http://www.environment.gov.au/fed/catalog/search/resource/details.page?uuid=\%7BD65D9FF0-218B-4884939D-904814A6D50F\%7D

Dixon, J.E. and K. Monteleone. 2014. Gateway to the Americas: Underwater archaeological survey in Beringia and the north Pacific. In Prehistoric Archaeology on the Continental Shelf: A Global Review (A.M. Evans, J.C. Flatman, and N.C. Flemming, eds.): 95-114. New York: Springer. https://doi.org/10.1007/978-14614-9635-9_6.

Dortch, C.E. 2002 Preliminary underwater survey for rock engravings and other sea floor sites in the Dampier Archipelago, Pilbara region, Western Australia. Australian Archaeology 54:37-42. https://doi.org/10.1080/03122417.2002.11681739.

Dortch, J., McDonald, J., Whitley, T. and Veth, P. 2017 Holocene transitions in shellfishing, Dampier Archipelago. Paper presented at AAA Conference in Melbourne.

Dortch, J., Beckett, E. Paterson, A and McDonald, J., nd First Australian evidence for a submerged coastal site? Stone artifacts in the intertidal zone, Dampier Archipelago. Short Report. Submitted to Australian Archaeology. Submitted paper.

Dunbar, J.S., S.D. Webb, and M.K. Faught. 1992. Archaeological sites in the drowned tertiary Karst Region of the Eastern Gulf of Mexico. In Paleo-Shorelines and Prehistory: An Investigation of Method (L. Johnson and M. Stright, eds.): 117-146. Boca Raton, Florida: CRC Press.

Erlandson, J.M. 2001. The archaeology of aquatic adaptations: Paradigms for a new millennium. Journal of Archaeological Research 9(4):287-350. https://doi.org/10.1023/A:1013062712695.

Erlandson, J.M. 2016. Seascapes of Santarosae: Paleocoastal seafaring on California's Channel Islands. In Marine Ventures: Archaeological Perspectives on Human-Sea Relations (H.B. Bjerck, H.M. Breivik, S.E. Fretheim, E.L. Piana, B. Skar, A.M. Tivoli and J. Zangrando, eds): 317-327. Sheffield, UK: Equinox.

Evans, A.M., J.C. Flatman, and N.C. Flemming (eds.). 2014. Prehistoric Archaeology on the Continental Shelf: A Global Review. London: Springer.

Faught, M.K. 2004. Submerged Paleoindian and Archaic sites of the Big Bend, Florida. Journal of Field Archaeology 29(3-4):273-290. https://doi.org/10.1179/jfa.2004.29.3-4.273.

Fedje, D.W. and H. Josenhans. 2000. Drowned forests and archaeology on the continental shelf of British Columbia, Canada. Geology 28(2):99-102. https://doi.org/10.1130/0091-701

7613(2000)28\%3C99:DFAAOT\%3E2.0.CO;2.

Filipova-Marinova, M., L. Giosan, H. Angelova, A. Preisinger, D. Pavlov, and S. Vergiev. 2011. Paleoecology of submerged prehistoric settlements in Sozopol Harbour, Bulgaria. In Submerged Prehistory (J. Benjamin, C. Bonsall, C. Pickard, and A. Fischer, eds.): 230-244. Oxford: Oxbow Books.

Fischer, A. 1993. Stone Age Settlements in the Småland Bight: A Theory Tested by Diving. København: Miljøministeriet, Skov- og Naturstyrelsen, 
Fischer, A. 1995. An entrance to the Mesolithic world below the ocean. Status of ten years' work on the Danish sea floor. In Man and Sea in the Mesolithic: Coastal Settlement Above and Below Present Sea Level (A. Fischer, ed.): 371-384. Oxbow Monograph 53. Oxford: Oxbow.

Flemming, N.C., J. Harff, D. Moura, A. Burgess, and G.N. Bailey (eds.). 2017. Submerged Landscapes of the European Continental Shelf: Quaternary Paleoenvironments. Chichester: John Wiley and Sons.

Gaffney, V., R. Allaby, R. Bates. M. Bates, E. Ch'ngm, S. Fitch, P. Garwood, G. Momber, P. Murgatroyd, M. Pallen, E. Ramsey, D. Smith, and O. Smith. 2017. Doggerland and the Lost Frontiers Project (20152020). In Under the Sea: Archaeology and Paleolandscapes of the Continental Shelf (G.N. Bailey, J. Harff, and D. Sakellariou, eds.): 305-319. Cham: Springer. https://doi.org/10.1007/978-3-319-53160-1_20.

Gaffney, V., S. Fitch, and D. Smith (eds.). 2009 Europe's Lost World: The Rediscovery of Doggerland. CBA Research Report 160. York: Council for British Archaeology.

Gaffney, V., K. Thomson, and S. Fitch (eds.). 2007. Mapping Doggerland: The Mesolithic Landscapes of the Southern North Sea. Oxford: Archaeopress.

Galili, E. and B. Rosen. 2011. Submerged Neolithic Settlements off the Carmel Coast, Israel : Cultural and environmental insights. In Submerged Prehistory (J. Benjamin, C. Bonsall, C. Pickard, and A. Fischer, eds.): 272-286. Oxford: Oxbow Books.

Geoscience. 2004. Geodata Coast 100K 2004. Shapefile. Canberra: Geoscience Australia, Department of Industry, Tourism and Resources. Last Modified 24/06/2017. https://data.gov.au/dataset/geodata-coast-100k2004

Geoscience. 2011. SRTM-derived 1 Second Digital Elevation Models Version 1.0. ESRI Grid. Canberra: Geoscience Australia, Department of Industry, Tourism and Resources. Last Modified 26/06/2018. https://data.gov.au/dataset/1-second-srtm-level-2-derived-digital-elevation-model-v1-0

Grøn, O. 2018. Some problems with modelling the positions of prehistoric hunter-gatherer settlements on the basis of landscape topography. Journal of Archaeological Science: Reports 20:192-199. https://doi.org/10.1016/j.jasrep.2018.04.034.

Hacker, J. 2017. LiDAR Data courtesy of Deep History of Sea Country 2017 Campaign.

Halligan, J.J., M.R. Waters, A. Perrotti, I.J. Owens, J.M. Feinberg, M.D. Bourne, B. Fenerty, B. Winsborough, D. Carlson, D.C. Fisher, T.W. Stafford Jr, and J.S. Dunbar. 2016. Pre-Clovis occupation 14,550 years ago at the Page-Ladson site, Florida, and the peopling of the Americas. Science Advances 2(5):e1600375. https://doi/org/10.1126/sciadv.1600375.

Hamm, G., P. Mitchell, L.J. Arnold, G.J. Prideaux, D. Questiaux, N.A. Spooner, V.A. Levchenko, E.C. Foley, T.H. Worthy, B. Stephenson, V. Coulthard, C. Coulthard, S. Wilton, and D. Johnston. 2016. Cultural innovation and megafauna interaction in the early settlement of arid Australia. Nature 539:280-283. http://dx.doi.org/10.1038/nature20125.

Harris, J. 1988. An Excavation Report of Georges Valley Shell Midden, Burrup Peninsula. BA Hons Dissertation. Perth: Department of Archaeology. University of Western Australia.

Hosfield, R.T., 2007. Terrestrial implications for the maritime geoarchaeological resource: a view from the Lower Paleolithic. Journal of Maritime Archaeology 2: 4-23. 
Jo McDonald Cultural Heritage Management Pty Ltd (JMcDCHM). 2005. Desktop Assessment of Scientific Values for Indigenous Cultural Heritage on the Dampier Archipelago, Western Australia. Report to the Heritage Division of the Department of Environment and Heritage, Canberra.

Jo McDonald Cultural Heritage Management Pty Ltd (JMcDCHM). 2006. A Study of the Distribution of Rock Art and Stone Structures on the Dampier Archipelago. Report to the Department of Environment and Heritage, Canberra.

Jo McDonald Cultural Heritage Management Pty Ltd (JMcDCHM). 2009. Archaeological Survey of Deep Gorge on the Burrup Peninsula (Murujuga) Dampier Archipelago WA. Report to the Department of Indigenous Affairs, Western Australia.

Kreij, A., J. Scriffignano, D. Rosendahl, T. Nagel, and S. Ulm. 2018. Aboriginal stone-walled intertidal fishtrap morphology, function and chronology investigated with high-resolution close-range Unmanned Aerial Vehicle photogrammetry. Journal of Archaeological Science 96:148-161.

https://doi.org/10.1016/j.jas.2018.05.012.

Larcombe, P., I.A.K. Ward, and T. Whitley. in press. Physical sedimentary controls on subtropical coastal and shelf sedimentary systems: Initial application in conceptual models and computer visualizations to support archaeology. Geoarchaeology. https://doi.org/10.1002/gea.21681.

Lorblanchet, M. 1976. Report on the Excavation of a Shell Midden at Skew Valley, Dampier WA. Working Paper. Canberra: Australian Institute of Aboriginal Studies.

Lorblanchet, M. 1977. Summary report of fieldwork, Dampier, WA. Australian Institute of Aboriginal Studies Newsletter (NS) 7.

Lorblanchet, M. 1978. Skew Valley Dampier, WA: Shell Middens and Rock Engravings. Unpublished manuscript. Canberra: Australian Institute of Aboriginal Studies.

Lorblanchet, M. 1983. Chronology of the rock engravings of Gum Tree Valley and Skew Valley near Dampier, WA. In Archaeology at ANZAAS 1983 (M. Smith, ed.): 39-59. Perth: Western Australian Museum.

Lorblanchet, M. 1992. The rock engravings of Gum Tree Valley and Skew Valley Dampier, WA: Chronology and functions of the sites. In State of the Art: Regional Rock art studies in Australia and Melanesia (J. McDonald and I.P. Haskovec, eds.): 39-47. Occasional AURA Publication 6. Melbourne: Rock Art Research Association.

Lourandos, H. 1997. Continent of Hunter-Gatherers: New Perspectives in Australian Prehistory. Cambridge: Cambridge University Press.

McDonald, J. 2015. I must go down to the seas again: Or, what happens when the sea comes to you? Murujuga rock art as an environmental indicator for Australia's north-west. Quaternary International 385:124-135. https://doi.org/10.1016/j.quaint.2014.10.056.

McDonald, J. and Berry, M. 2016. Murujuga, northwestern Australia: When arid hunter-gatherers became coastal foragers. Journal of Island and Coastal Archaeology 12(1):24-43.

https://doi.org/10.1080/15564894.2015.1125971.

McDonald, J., Dortch, J., Paterson, A., Veth P. (in prep. 2019) Murujuga: Dynamics of the Dreaming. Monograph to be published by Terra Australis. With contributions by Mulvaney, Whitley, Hampson, de Koning, Jeffreys, Beckett, Anderson, Leopold, Bourke and Dowding. 
McDonald, J., W. Reynen, K. Ditchfield, J. Dortch, M. Leopold, B. Stephenson, T. Whitley, I. Ward, and P. Veth. 2018a. Murujuga Rockshelter: First evidence for Pleistocene occupation on the Burrup Peninsula. Quaternary Science Reviews 193: 266-287. https://doi.org/10.1016/j.quascirev.2018.06.002.

McDonald J., Reynen W., Petchey F., Ditchfield K., Byrne C., Vannieuwenhuyse D., Leopold, M. and P. Veth 2018b Karnatukul (Serpent's Glen): A new chronology for the oldest site in Australia's Western Desert. PLoS ONE 13(9): 0202511. https://doi.org/10.1371/journal.pone.0202511 pmid:30231025

McDonald, J. and P. Veth. 2009. Dampier Archipelago petroglyphs: Archaeology, scientific values and National Heritage Listing. Archaeology in Oceania 44:49 -69. https://doi.org/10.1002/j.18344453.2009.tb00068.x.

McNiven, I.J. and S. Ulm (eds.). 2015. Multidisciplinary Approaches to Australian Island Pasts: Late Pleistocene to Historical Perspectives on Australian Island Use. Quaternary International 385.

Maloney, T., S. O’Connor, R. Wood, K. Aplin, and J. Balme. 2018. Carpenters Gap 1: A 47,000 year old record of indigenous adaption and innovation. Quaternary Science Reviews 191:204-228.

https://doi.org/10.1016/j.quascirev.2018.05.016.

Manne, T. and P.M. Veth. 2015. Late Pleistocene and early Holocene exploitation of estuarine communities in northwestern Australia. Quaternary International 385:112-123.

https://doi.org/10.1016/j.quaint.2014.12.049.

Missiaen, T., D. Sakellariou, and N. Flemming. 2017. Survey Strategies and Techniques in Underwater Geoarchaeological Research: An Overview with Emphasis on Prehistoric Sites. In Under the Sea: Archaeology and Palaeolandscapes of the Continental Shelf (Bailey G., J. Harff, and D. Sakellariou, eds): 21-37. Coastal Research Library, vol 20. Cham: Springer. https://doi.org/10.1007/978-3-319-53160-1_2.

Moree, J.M. and M.M. Sier (eds.). 2015. Interdisciplinary Archaeological Research Programme Maasvlakte 2, Rotterdam. BOORrapporten 566. BOOR, Rotterdam.

Mulvaney, K.J. 2015. Murujuga Marni: Rock Art of the Macropod Hunters and Mollusc Harvesters. CRAR+M Monograph Series 1. Perth: UWA Press.

Nearmap 2018. Western Australia Latest. Accessed 28/08/2018. https://www.nearmap.com.au/

O'Connor, S. and P. Veth. 1993. Where the desert meets the sea: A preliminary report of the archaeology of the southern Kimberley coast. Australian Archaeology 37:25-34.

https://doi.org/10.1080/03122417.1993.11681493.

O'Connor, S. and P. Veth (eds.). 2000. East of Wallace's Line: Studies of Past and Present Maritime Cultures in the Indo-Pacific Region. Modern Quaternary Research in South East Asia 16. Rotterdam: A.A. Balkema.

O’Shea, J.M., A.K. Lemke, E.P. Sonnenburg, R.G. Reynolds, and B.D. Abbott. 2014. A 9,000-year-old caribou hunting structure beneath Lake Huron. Proceedings of the National Academy of Sciences USA, 111(19):6911-6915. https://doi.org/10.1073/pnas.1404404111.

Pearson, C.E., R.A. Weinstein, S.M. Gagliano and D.B. Kelley. 2014. Prehistoric site discovery on the outer continental shelf, Gulf of Mexico, United States of America. In Prehistoric Archaeology on the Continental Shelf: A Global Review (A.M. Evans, J.C. Flatman, and N.C. Flemming, eds.): 53-72. New York: Springer. https://doi.org/10.1007/978-1-4614-9635-9_4. 
Pillans, B. and L.K. Fifield. 2014. Erosion rates and weathering history of rock surfaces associated with Aboriginal rock art engravings (petroglyphs) on Burrup Peninsula, Western Australia, from cosmogenic nuclide measurements. Quaternary Science Reviews 69:98-106.

https://doi.org/10.1016/j.quascirev.2013.03.001.

Reynen, W. and K. Morse. 2016. Don't forget the fish - Towards an archaeology of the Abydos Plain, Pilbara, Western Australia. Australian Archaeology 82(2):94-105.

https://doi.org/10.1080/03122417.2016.1203138.

Semeniuk, V. 1994. Predicting the effect of sea-level rise on mangroves in northwestern Australia. Journal of Coastal Research 10(4):1050-1076.

Semeniuk, V. 2013. Predicted response of coastal wetlands to climate changes: A western Australian model. Hydrobiologia, 708: 23-43.

Sullivan, M., P. Hughes, and A. Barham. 2011. Abydos Plain - Equivocal archaeology. Technical Reports of the Australian Museum 23(2):7-29.

Tizzard, L., A. Bicket, J. Benjamin, and D. Deloecker. 2014. A Middle Palaeolithic site in the southern North Sea: investigating the archaeology and palaeogeography of Area 240. Journal of Quaternary Science 29(7):698-710.

Tizzard, L., A. Bicket, and D. De Loeker. 2015. Seabed Prehistory: Investigating the Paleogeography and Early Middle Paleolithic Archaeology in the Southern North Sea. Wessex Archaeology Monograph 35. Salisbury: Wessex Archaeology.

Ulm, S. 2011 Coastal foragers on southern shores: Marine resource use in northeast Australia since the late Pleistocene. In Trekking the Shore: Changing Coastlines and the Antiquity of Coastal Settlement (N.F. Bicho, J.A. Haws, and L.G. Davis, eds.): 441-461. New York: Springer. https://doi.org/10.1007/978-1-44198219-3_19.

Veth, P., E Bradshaw, T Gara, N Hall, P Haydock, and P Kendrick. 1993. Burrup Peninsula Aboriginal Heritage Project. Western Australia: a report to the Department of Conservation and Land Management.

Veth, P.M. 1982. Testing the Behavioral Model: The Use of Open Site Data. BA (Hons) Dissertation. Perth: University of Western Australia.

Veth, P., K. Aplin, L.A. Wallis, T. Manne, T. Pulsford, E. White, and A. Chappell. 2007. The Archaeology of the Montebello Islands, North-West Australia Late Quaternary Foragers on an Arid Coastline. British Archaeological Reports International Series S1668. Oxford: Archaeopress.

Veth, P., K. Ditchfield, and F. Hook. 2014. Maritime deserts of the Australian northwest. Australian Archaeology 79:156-166. https://doi.org/10.1080/03122417.2014.11682032.

Veth, P., T. Gara, and P. Kendrick. 1994. The Aboriginal face of rock engravings on the Burrup Peninsula. In Archaeology in the North: Proceedings of the Australian Archaeological Association Conference (M.

Sullivan, S. Brockwell, and A. Webb, eds): 213-226. Darwin, North Australia Research Unit.

Veth, P., I. Ward, and K. Ditchfield. 2017b. Reconceptualising Last Glacial Maximum discontinuities: A case study from the maritime deserts of north-western Australia. Journal of Anthropological Archaeology 46: 82-91. https://doi.org/10.1016/j.jaa.2016.07.016.

Veth, P., I. Ward, T. Manne, S. Ulm, K. Ditchfield, J. Dortch, F. Hook, F. Petchey, A. Hogg, D. Questiaux, M. Demuro, L. Arnold, N. Spooner, V. Levchenko, J. Skippington, C. Byrne, M. Basgall, D. Zeanah, D. 
Belton, P. Helmholz, S. Bajkan, R. Bailey, C. Placzek, and P. Kendrick. 2017a. Early human occupation of a maritime desert, Barrow Island, north-west Australia. Quaternary Science Reviews 168:19-29.

https://doi.org/10.1016/j.quascirev.2017.05.002.

Vinnicombe, P. 1987. Dampier Archaeological Project: Resource Document, Survey and Salvage of Aboriginal Sites, Burrup Peninsula, Western Australia. Perth: Western Australian Museum.

Vinnicombe, P. 2002. Petroglyphs of the Dampier Archipelago: Background to development and descriptive analysis. Rock Art Research 19(1):3-27.

Ward, I. 2014. Depositional context as the foundation to determining the Paleolithic and Mesolithic archaeological potential of offshore wind farm areas in the southern North Sea. Conservation and Management of Archaeological Sites 16(3):212-235. https://doi.org/10.1179/1350503315Z.00000000083.

Ward, I., P. Larcombe, K. Mulvaney, and C. Fandry. 2013. The potential for discovery of new submerged archaeological sites near the Dampier Archipelago, Western Australia. Quaternary International, 308309:216-229. https://doi.org/10.1016/j.quaint.2013.03.032.

Ward, I.A.K., P. Larcombe, and P. Veth. 1999. A new process-based model for wreck site formation. Journal of Archaeological Science 26(5):561-570. https://doi.org/10.1006/jasc.1998.0331.

Ward, I., P. Larcombe, and P. Veth. 2015. A new model for coastal resource productivity and sea-level change: The role of physical sedimentary processes in assessing the archaeological potential of submerged landscapes from the Northwest Australian continental shelf. Geoarchaeology 30(1):19-31.

https://doi.org/10.1002/gea.21498.

Ward, I., Larcombe, P., Carson, A., Lane, A. 2016. Archaeological assessment of coastal and marine development sites: case study from James Price Point, WA. J. Roy. Soc. WA, 99(2), 31-46. 